\title{
Engineering Drought Resistance in Forest Trees
}

\author{
Andrea Polle ${ }^{1,2,3 *}$, Shao Liang Chen ${ }^{1}$, Christian Eckert ${ }^{2}$ and Antoine Harfouche ${ }^{4}$ \\ ${ }^{1}$ Beijing Advanced Innovation Center for Tree Breeding by Molecular Design, College of Biological Sciences and Technology, \\ Beijing Forestry University, Beijing, China, ${ }^{2}$ Forest Botany and Tree Physiology, University of Goettingen, Göttingen, Germany, \\ ${ }^{3}$ Centre of Biodiversity and Sustainable Land Use, University of Goettingen, Göttingen, Germany, ${ }^{4}$ Department for Innovation \\ in Biological, Agrofood and Forest systems, University of Tuscia, Viterbo, Italy
}

\section{OPEN ACCESS}

Edited by:

Wout Boerjan,

Flanders Institute for Biotechnology,

Belgium

Reviewed by:

Christine Helen Foyer,

University of Leeds, United Kingdom

Chung-Jui Tsai,

University of Georgia, United States

*Correspondence:

Andrea Polle apolle@gwdg.de

Specialty section:

This article was submitted to

Plant Biotechnology,

a section of the journal

Frontiers in Plant Science

Received: 10 August 2018 Accepted: 04 December 2018

Published: 08 January 2019

Citation:

Polle A, Chen SL, Eckert C and Harfouche A (2019) Engineering Drought Resistance in Forest Trees.

Front. Plant Sci. 9:1875.

doi: 10.3389/fp/s.2018.01875
Climatic stresses limit plant growth and productivity. In the past decade, tree improvement programs were mainly focused on yield but it is obvious that enhanced stress resistance is also required. In this review we highlight important drought avoidance and tolerance mechanisms in forest trees. Genomes of economically important trees species with divergent resistance mechanisms can now be exploited to uncover the mechanistic basis of long-term drought adaptation at the whole plant level. Molecular tree physiology indicates that osmotic adjustment, antioxidative defense and increased water use efficiency are important targets for enhanced drought tolerance at the cellular and tissue level. Recent biotechnological approaches focused on overexpression of genes involved in stress sensing and signaling, such as the abscisic acid core pathway, and down-stream transcription factors. By this strategy, a suite of defense systems was recruited, generally enhancing drought and salt stress tolerance under laboratory conditions. However, field studies are still scarce. Under field conditions trees are exposed to combinations of stresses that vary in duration and magnitude. Variable stresses may overrule the positive effect achieved by engineering an individual defense pathway. To assess the usability of distinct modifications, large-scale experimental field studies in different environments are necessary. To optimize the balance between growth and defense, the use of stress-inducible promoters may be useful. Future improvement programs for drought resistance will benefit from a better understanding of the intricate networks that ameliorate molecular and ecological traits of forest trees.

Keywords: water limitation, antioxidative systems, genetic engineering, forest tree species, isohydric, anisohydric, avoidance, tolerance

\section{INTRODUCTION}

Forests cover about $30 \%$ of the terrestrial land (FAO, 2016). They have strong effects on the local climate (Li et al., 2015), by interacting with biogeochemical water cycles (Ellison et al., 2017). When forest trees die or forests are cleared across large-scale landscapes, the negative consequences of drought are aggravated (Allen et al., 2015; Reyer et al., 2015), as shown for many areas world-wide (Laurance, 1998, 2004; van der Werf et al., 2008; Malone, 2017). Over-utilization of forests as a feedstock for energy, construction materials, or the generation of value-added products for the chemical industries, intensifies the problem.

The negative consequences of drought become even more urgent in current times of climate change because projections suggest that such events will occur more frequently and be more 
extreme (Allen et al., 2010; Reyer et al., 2015). In the past decades, global warming has resulted in a drastic reduction of ice-covered northern polar areas during summer (NSIDC, 2018). Over smaller polar areas air temperatures are cooling down less, thus, resulting in lower differences between boreal, temperate and tropical areas. A possible climate implication of this atmospheric situation is an effect on jet-stream oscillation, which in turn may extend stable meteorological high- and low-pressure (anticyclone/cyclone) conditions; the consequences of such conditions are manifested in periods of precipitation on the one hand, and periods of drought on the other hand (Schaller et al., 2018). During lows, flooding events are frequent, whereas the long-lasting highs lead to scarcity of water in many regions world-wide (FAO, 2016). The dry spells promote salt accumulation in upper soil layers, soil degradation, and erosion (Polle and Chen, 2015). Salt and drought are, thus, often cooccurring stresses with which plants have to cope although their physiological implications vary to some extent (Chen and Polle, 2010; Polle and Chen, 2015). The current review is focused on tree responses and improvement by genetic engineering in response to drought. Since most studies in which trees were ameliorated for improved stress resistance included both drought and salt, salinity cannot be completely ignored.

In this review we highlight the molecular physiology of drought stressed forest trees and present an overview on recent biotechnological approaches to improve the drought tolerance of trees with a focus on yield and enhanced stress resistance. Drought effects on woody plants and measures for tree improvements have regularly been reviewed (Wang et al., 2003; Polle et al., 2006; Rennenberg et al., 2006; Fischer and Polle, 2010; Harfouche et al., 2014). Therefore, this review briefly recapitulates the molecular physiology of drought and salt tolerance mechanisms. We summarize novel studies, published in the past 5 years on the performance of trees engineered for better osmotic resistance. We also pinpoint research gaps that need to be addressed for future improvement of drought resistance in trees.

\section{Concepts and Strategies}

Growth and reproduction of plants requires access to water. Water is the solvent for nutrients in soil, the transport medium for nutrients in the plants and the solvent for cellular solutes. Because water is essentially the "stuff of life", the plant water status is tightly controlled by a multitude of general and specific measures such as stomatal control on water loss (Buckley, 2005; Daszkowska-Golec and Szarejko, 2013), osmotic adjustment (Harfouche et al., 2014), anatomical adjustment of the water conducting system (Sperry and Love, 2015; Leuschner and Meier, 2018), deposition of cuticular waxes (Hadley and Smith, 1990) and morphological adjustments such as leaf shedding to avoid uncontrolled desiccation (Munné-Bosch and Alegre, 2004; Fischer and Polle, 2010). Periods of severe and long-lasting drought threaten the existence of plants when overruling their acclimation capacities. These broad examples show that drought responses act at different scales, i.e., inside the plant body and at the level of populations; the responses occur at different time scales, and thus, invoke short- and long-term adjustments that can be flexible or reflect evolutionary adaptation (Figure 1). As a result, drought resistance can be achieved by avoidance (homeostasis of tissue water status) or by tolerance mechanisms (acclimation that enable metabolism at a low water potential) (Levitt, 1980; Jones, 1993). These distinctions are important when considering strategies for engineering drought resistance in tree species.

Avoidance mechanisms generally act at the scale of organs or at the whole-plant and the species level (Figure 1). Drought adaptation is characterized by ecological traits such as leaf thickness, root morphology, leaf shedding, etc. It is obvious that these traits are the result of a distinct developmental repertoire in a given species. Due to their presumed complexity they have rarely been incorporated in molecular breeding programs. However, the availability of increasing number of tree reference genomes may open new avenues to better understanding and exploiting their ecological traits. For example, the genomes of European beech (Fagus sylvatica) and pedunculate oak (Quercus robur) have recently been published (Mishra et al., 2018; Plomion et al., 2018). These two species are closely related members of the Fagaceae but exhibit strongly divergent ecological behavior (Aranda et al., 2015; Roman et al., 2015). Beech has a shallow fine root system, while oak has a deep root system (Leuschner and Meier, 2018). Deeper tree roots make a valuable contribution to drought resistance and thus, root morphology is one of the traits targeted for improving water use by capturing subsoil water. At the whole-plant level drought stress avoidance is dependent on the capability of the tree to minimize loss and maximize uptake of water (Chaves et al., 2003) through stomatal control and extensive, deep root systems (Nguyen and Lamant, 1989; Brodribb et al., 2010). We envisage that exploiting genomic information, for instance by comparing the molecular differences in root development of important forest species such as beech and oak, novel approaches that could direct breeding for drought avoidance may become available.

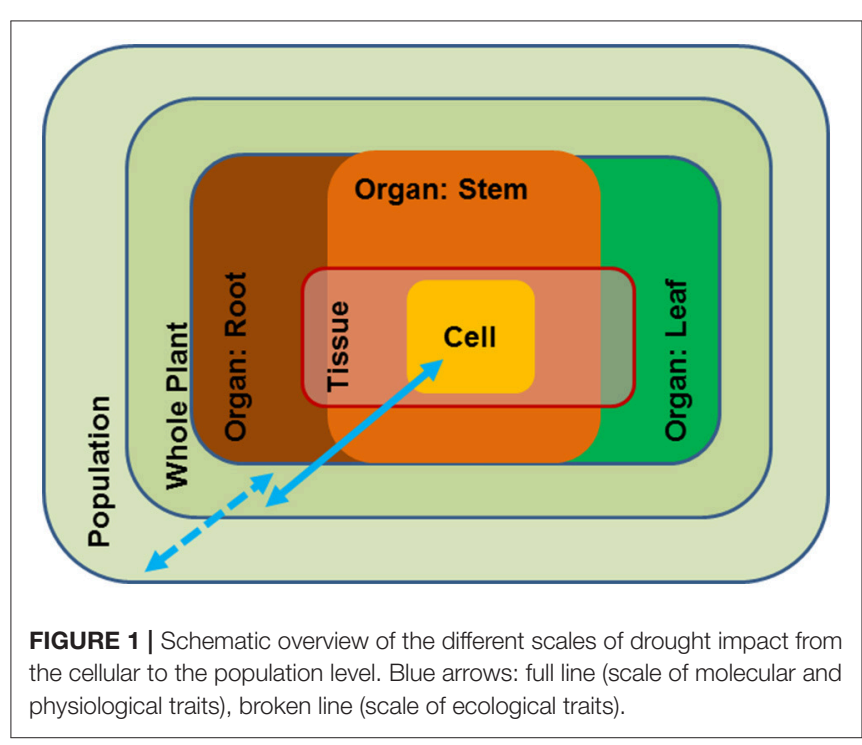


Another interesting example for drought avoidance is leaf shedding, a common phenomenon in tropical dry forests (Wolfe et al., 2016). Leaf shedding is controlled by an intricate interplay of phytohormones, including ethylene, abscisic acid (ABA), and auxin (González-Carranza et al., 1998; Chen et al., 2002a,b; Jin et al., 2015; Paul et al., 2018), which could be harnessed to improve tree drought resistance. In polyploid poplars regenerated from protoplast fusion accelerated droughtinduced leaf shedding was observed that resulted in increased tree survival under extreme drought (Hennig et al., 2015). The exact genetic basis of this phenotype is not known but it is apparently associated with partial genome duplication (Hennig, 2016).

Trees must exist in their environment over decades and centuries and therefore require not only drought adaptedness but also metabolic flexibility to adjust their metabolism to changing conditions. Drought tolerance is usually achieved by biochemical modification of the cellular metabolism (Figure 1). Acclimation to drought by an individual plant invokes changes in membrane composition, protection of protein folding, osmotic adjustment, scavenging of reactive oxygen species (ROS), etc. (Harfouche et al., 2014) and, thus, acts at the level of cells to organs (Figure 1). An important feature of plant drought tolerance is the increase in osmotic pressure as a countermeasure to maintain water flux under declining soil water potentials. The production of osmolytes is costly in terms of carbohydrates because it diverts carbohydrates from growth to defense. A striking example of how woody species from arid, saline deserts can economize their carbon budget is the succulent xerophyte Zygophyllum xanthoxylum (Janz and Polle, 2012). This species exploits sodium as a "cheap" osmolyte, thereby, improving photosynthesis and growth under harsh environmental conditions (Ma et al., 2012). The discovery of such amelioration mechanisms constitutes an important basis to improve drought tolerance in trees (Bao et al., 2015, more details are found below) and underpins our understanding of the physiological consequences of novel features, which is crucial to harness the critical molecular mechanisms for drought acclimation and adaptation.

\section{MOLECULAR PHYSIOLOGY OF OSMOTIC STRESSES}

\section{Roots}

Roots are the first organ to sense and signal soil water deficits (Hamanishi and Campbell, 2011; Brunner et al., 2015). Since enhanced salinity decreases water availability to roots by increasing the osmotic potential in soil solution, the consequences for water uptake are partly similar to those of drought. Both drought and salt result in a decline in root-toshoot water flow in poplars (Chen et al., 1997, 2002b; Shi et al., 2010), but the consequences are generally less severe in salt tolerant than in sensitive species (Chen et al., 2002b,c, 2003).

At the biochemical level, increased ABA concentrations are a hallmark of osmotic stress across all organs (Wasilewska et al., 2008; Kuromori et al., 2018) (Figure 2). The stress signal ABA interacts with pyrabactin resistance 1 (PYR1)/PYR1like (PYL)/regulatory components of ABA receptors (RCAR) proteins, which then can then form a complex with PP2Cs (Type 2C phosphatases). Thereby, phosphorylation of a SnRK (Kinase) is enabled, which subsequently activates down-stream transcription factors and target genes (Fujita et al., 2011; de Zelicourt et al., 2016). Transcriptomic analyses of pine and poplar roots under drought revealed upregulation of genes for ABA biosynthesis [9-cis-epoxycarotenoid dioxygenase (NCED)], signaling and response factors such as DREB1, bZIP, AP2/ERF, $M Y B, N A C$, and WRKY (Wilkins et al., 2009; Cohen et al., 2010; Lorenz et al., 2011; Perdiguero et al., 2012). Salinity and drought share similar response patterns in poplar roots, which are likely mediated by ABA (Chen et al., 1997, 2001, 2002b; Luo et al., 2009).

$\mathrm{ABA}$ in roots further promotes increased biosynthesis of proline (Davies and Bacon, 2003). High concentrations of proline may act as osmolyte and contribute to osmotic adjustment; a further possible function of proline is the protection of appropriate protein folding (Claeys and Inzé, 2013). However, only a few studies have demonstrated increases in proline concentrations in the roots of trees in response to drought stress (Cocozza et al., 2010; Naser et al., 2010). This casts doubts on a prominent role of proline as an osmolyte in roots. Another function of ABA biosynthesis and transport in roots may be related to stimulate endodermal suberization (Tan et al., 2003; Koiwai et al., 2004; Kuromori et al., 2010; Kanno et al., 2012; Zhang et al., 2014). A recent study demonstrated that endodermis is reversibly impregnated with hydrophobic compounds such as suberin in response to abiotic stresses, which might restrict apoplastic movement of water (Barberon et al., 2016).

Evidence is accumulating that ABA plays a role in regulating hydraulic conductance in roots possibly via aquaporin activity (Parent et al., 2009; Almeida-Rodriguez et al., 2011). At the molecular level, aquaporins are important for the control of water

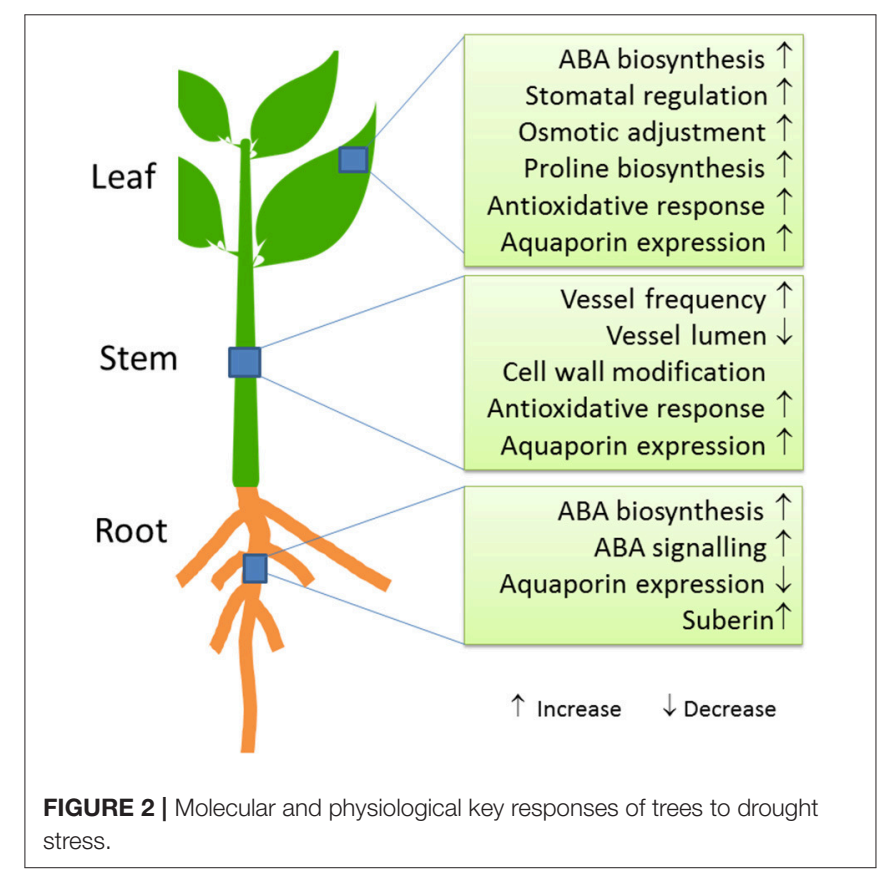


uptake (Fox et al., 2017). Since contrasting responses to different osmotic stress factors have been observed, their regulation is still unclear. For example, changes in the evaporative demand resulted in aquaporin upregulation (Parent et al., 2009; AlmeidaRodriguez et al., 2011), while drought or salt stress caused declines in their expression (Bogeat-Triboulot et al., 2007; Wang et al., 2017a). A decrease in aquaporins in roots is supposed to increase cellular water conservation due to reduced membrane water permeability during periods of dehydration stress (Smart et al., 2001; Bogeat-Triboulot et al., 2007) and would fit with the observed restriction of apoplastic water loss by enhanced suberization (Barberon et al., 2016).

Mycorrhizal fungi also increase tree stress tolerance by regulation of aquaporins and stress metabolites (Luo et al., 2009; Dietz et al., 2011; Xu et al., 2015; Peter et al., 2016), but an indepth treatment of this aspect is beyond the scope of this review. The reader is advised to consult Brunner et al. (2015).

\section{Stem}

Physiological responses of trees to drought stress lead to hydraulic and carbon cycle adjustments (Parker, 1956; Bréda et al., 2006). The hydraulic architecture of the stem is important to keep up water transport under drought and re-establish water flux after re-irrigation. Hydraulic acclimation can be achieved by increased vessel frequencies and decreased vessel lumina (Hacke et al., 2006). Drought-resistant trees decrease the ratio of vessel lumen to cell wall thickness to enhance wall strength under water stress (Hacke et al., 2001) (Figure 2). While the anatomy and biophysics of xylem adjustment to water-limited conditions has often been studied (Tyree and Ewers, 1991; Anderegg, 2015; Sperry and Love, 2015), our knowledge on the molecular processes underlying these changes is limited. Aquaporins (PIP1 family) are important for refilling of embolized vessels and thereby helping the tree to recover after drought (Secchi and Zwieniecki, 2011; Laur and Hacke, 2014).

Anatomical and transcriptomic analyses of the developing xylem of poplars revealed that drought imposed changes that are similar to those found after salt exposure (Junghans et al., 2006; Bogeat-Triboulot et al., 2007; Janz et al., 2012; Wildhagen et al., 2018). For example, salt stressed poplar trees reinforce cell walls by increasing wall thickness relative to lumen area and avoid a strong loss in hydraulic conductivity by enhancing vessel frequency (Janz et al., 2012). Transcript abundances of of genes encoding fasciclin-like arabinogalactans (FLA), COBRA-like proteins, xyloglucan-endo-transglycolyases, pectin methylesterases were jointly repressed in developing xylem, while those of genes activating stress and defense responses increased (Janz et al., 2012). Similarly, in water-stressed poplars, transcript abundances of several cellulose synthases, arabinogalactan (AGP) and fasciclin-like proteins decreased (Berta et al., 2010). Wildhagen et al. (2018) also reported massive changes in the regulation of genes required for cell wall forming enzymes. Unexpectedly, drought decreased lignin and increased the saccharification potential of the wood (Wildhagen et al., 2018), indicating positive changes with regard to the biotechnological usage of wood. It would therefore be worthwhile to test whether these changes can be achieved without the typical drought-induced growth-defense trade-off.

Drought further activates antioxidant defenses in the cambium of different poplar clones [Dvina ( $P$. deltoides), I-214 (P. × canadensis), Pallara et al., 2012]. A distinct isoform of CATALASE 3 (CAT3) was strongly enhanced under water deficit, unpinning an essential role for this enzyme in ROS control under drought stress (Pallara et al., 2012). Furthermore, increases in the concentrations of osmotically active solutes in the cambial region of $P$. alba accompanied reductions in predawn leaf water potentials and stem dehydration (Pallara et al., 2012).

\section{Leaves}

Stomatal regulation is one of the most important mechanisms to adjust water consumption to fluctuations in water availability (Tardieu and Simonneau, 1998; McDowell et al., 2008; Skelton et al., 2015). Regulation of stomatal aperture reduces water loss by leaf transpiration (Stålfelt, 1955; Barrs, 1971; Brodribb and Holbrook, 2003; Araújo et al., 2011) but there is a trade-off between transpirational water loss and $\mathrm{CO}_{2}$ assimilation (Jarvis and Jarvis, 1963; Cowan, 1978). Pioneering studies involving poplar species and hybrids shed light on two drought stress response strategies, anisohydric and isohydric behavior with divergent consequences for water flux and biomass production (Marron et al., 2003; Monclus et al., 2006; Giovannelli et al., 2007). Anisohydric plants keep their stomata relatively widely open and prevent dehydration by increasing the osmotic pressure in leaves (Gebre et al., 1994; Marron et al., 2002; Hanin et al., 2011; Barchet et al., 2014; Martorell et al., 2015); thereby, they are capable to support growth and biomass production (Passioura, 2002). Isohydric plants limit water loss through sensitive stomatal regulation and closure and/or by leaf abscission (Couso and Fernández, 2012). Poplars are isohydric species but exhibit a suite of adaptive measures (Brignolas et al., 2000) such as variation in stomatal sensitivity (Hamanishi et al., 2012), leaf shedding (Marron et al., 2002) and growth decline (Giovannelli et al., 2007). In a population of tree species a continuum of responses to water deficit between isohydryic and anisohydric behavior can be found (Klein, 2014). For instance, beech generally exhibits isohydric behavior but progenies from dry habitats showed stronger anisohydric behavior than those from wet habitats (Nguyen et al., 2017). In poplar, heritability of stomatal responsiveness to water deficit is generally high, indicating that this trait is a useful target for genetic engineering (Orlovic et al., 1998; Al Afas et al., 2006; Monclus et al., 2006).

Endogenous ABA is rapidly produced upon water deficit, initiating a signaling cascade that results in down-stream responses such as stomatal closure (Fujii et al., 2009). Besides roots, ABA biosynthesis takes place in leaves (Kuromori et al., 2018). Stomatal responsiveness to ABA shows large variation among different species and is evolutionary determined (Sussmilch et al., 2017). In angiosperms, ABA induced stomatal closure is usually rapid and can occur within seconds or minutes (Geiger et al., 2011), thus, not requiring de novo transcription. Over-expression of the ABA biosynthesis protein 9-cis-epoxycarotenoid dioxygenase 3 (NCED3) is beneficial for water-use efficiency (WUE) and results in enhanced drought 
resistance in several plant species (Iuchi et al., 2001; Tung et al., 2008). Drought induced changes in stomatal development involve regulation of transcript abundance of the poplar orthologs of STOMAGEN, ERECTA, and STOMATA DENSITY AND DISTRIBUTION 1 (SDD1) (Harfouche et al., 2014). Interestingly, WUE was increased by the over-expression of a poplar ortholog of ERECTA in A. thaliana (Xing et al., 2011). ERECTA controls stomatal density but the sequence of events leading to this effect is still unknown (Xing et al., 2011). Genes such as ERECTA, SDD1, or NCED3 should be the focus of future research programs aimed at developing transgenic or geneedited trees with resistance to naturally occurring field drought conditions.

At the cellular level, biochemical protection measures are activated in response to drought to avoid negative consequences of stress-induced ROS and to endure water deficit (Wang et al., 2003, Figure 2). Moderate water stress results in increased concentrations of soluble carbohydrates and polyols, which potentially promote maintenance of cell turgor in P. euphratica leaves through increased osmotic pressure (Bogeat-Triboulot et al., 2007). However, after salt acclimation bulk soluble carbohydrates (including glucose and fructose, sucrose), sugar alcohols, organic acids, mostly decrease or remain almost unaffected (Ottow et al., 2005; Dluzniewska et al., 2007; Ehlting et al., 2007; Brinker et al., 2010), suggesting that moderate salt accumulation in leaves may compensate for osmotic adjustment as observed in some halophytic species (Ma et al., 2012). It is noteworthy that amino acids, in particular proline, increase drastically in both water- and salt-stressed leaves (Brosché et al., 2005; Ottow et al., 2005; Dluzniewska et al., 2007; Ehlting et al., 2007; Pallara et al., 2012). In accordance, the mRNA levels of genes encoding enzymes that catalyze rate-limiting steps of proline synthesis and degradation [delta-1-pyrroline5-carboxylate synthase (PcP5CS) and proline dehydrogenase] accumulate under osmotic stress (Dluzniewska et al., 2007). However, the bulk rise of proline to $\mu \mathrm{M}$ levels is insufficient to explain the observed change in osmotic pressure in salt exposed trees required to maintain water uptake (Ottow et al., 2005; Brinker et al., 2010). Therefore, increased proline may act as a protectant of protein integrity rather than function as an osmolyte in leaves.

Antioxidative systems also play an important role in the defense against negative consequences of drought stress (Hasanuzzaman et al., 2013). Therefore, one would expect that populations of wild tree species (beech) from dry conditions contain higher ROS protection than those from mesic conditions. Unexpectedly, the opposite was observed: unstressed beech from a mesic habitat showed a higher antioxidative capacity than those from a dry habitat and moreover, those from mesic conditions showed a stronger antioxidative response to drought than those from the dry habitat (Carsjens et al., 2014). These observations suggest that trees exposed infrequently to stress respond more flexibly, whereas long-term stress adapted trees are protected by resistance measures, which are already in place before the onset of acute stress. This view is also supported by constitutively enhanced salt tolerance of $P$. euphratica compared to salt sensitive poplars (Janz et al., 2010). The enhanced tolerance of $P$. euphratica is, for example, based on the expansion of the sodium:proton antiporter family in the genome of this species (Ma et al., 2013). These few and selective examples highlight that divergent strategies may be required for improving drought resistance in short- or long-term water limited environments.

\section{GENETIC APPROACHES FOR INCREASED STRESS TOLERANCE}

Because drought and other osmotic stresses result in multiple tolerance or avoidance mechanisms, simple strategies for improving the performance of trees in water-limited environments do not exist. In order to target a suite of genes that can enhance drought tolerance, recent attempts to improve plant performance have often focused on signal perception and transduction (Table 1), whereas overexpression of structural genes found fewer applications (Table 2). Strategies for the selection of candidate genes relied mainly on the inducibility of genes under stress or on the gene origin in a highly stress tolerant species (Tables 1, 2).

In most cases, candidate genes for stress tolerance were expressed under the $35 \mathrm{~S}$ promoter, leading to high constitutive production in the transgenic plant (Table 1). A drawback of this approach is that more drought resistant plants often show biomass yield trade-off (e.g., the dwarfed eui mutant, a mutant in the GA-regulating CYP714 A3 gene, Wang C. et al., 2016). The utilization of stress-inducible promoters may be promising to achieve a balance between growth under non-stress conditions and enhanced defense activation under drought conditions. For example, a novel zinc finger protein from the succulent, xerophytic species $Z$. xanthoxylum rendered transgenic plants more tolerant to osmotic stress (Chu et al., 2016; Table 1). Similarly, overexpression of $D R E B$ (dehydration responsive protein binding element) under the $R D 29$ promoter activated osmolytes (sugars) and enhanced the performance of transgenic plants under drought stress (Zhou et al., 2012; Table 1). Other studies showed successful activation of antioxidants, reduction of membrane leakage and increased photosynthesis, when YUCCA6 (a flavin mono-oxygenase-like from Arabidopsis thaliana) or choline oxidase (from bacteria) were overexpressed under an oxidative stress-inducible promoter (Ke et al., 2015, 2016; Table 2). However, overall utilization of stress-inducible promoters is still rare.

Plant model species, in which drought responses have often been studied and for which genomic information is available for a decade or longer, such as A. thaliana and Populus spp. were often used as the source species of inducible genes. In recent years, the gene pool of drought and salt tolerant woody species has increasingly been tapped. Among these species are: the succulent, xerophyte $Z$. xanthoxylum, the salt-tolerant and facultative succulent poplar, P. euphratica, the salt- and droughttolerant species, Tamarix hispida and the salt-tolerant Fraxinus velutina (Tables 1, 2). Other crops and woody species that have also been increasingly used as gene source are: Diospyros kaki (a widely cultivated fruit tree in China), Phyllostachys edulis (bamboo), Morus spp. (mulberry, feed for silkworms), 


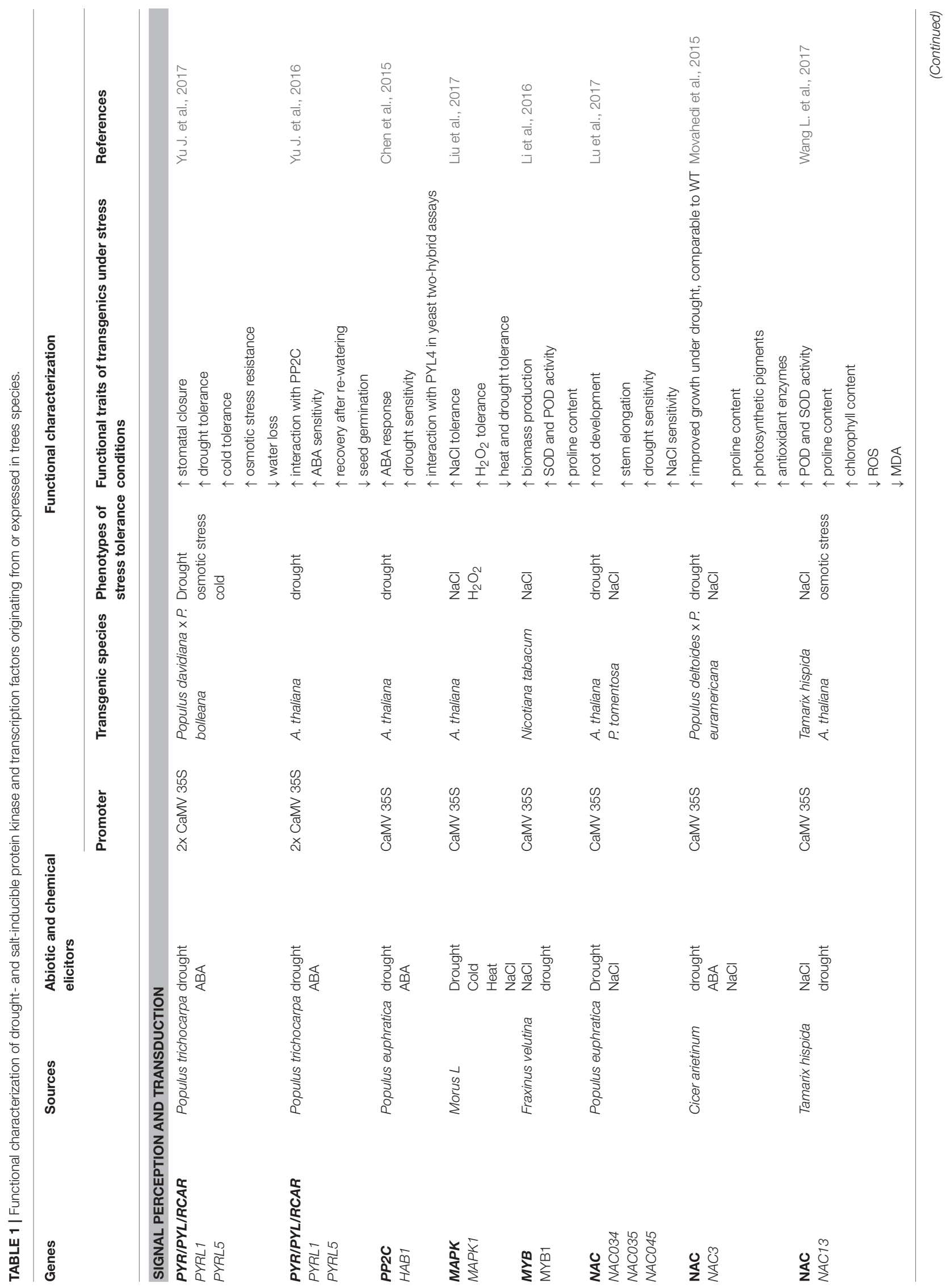




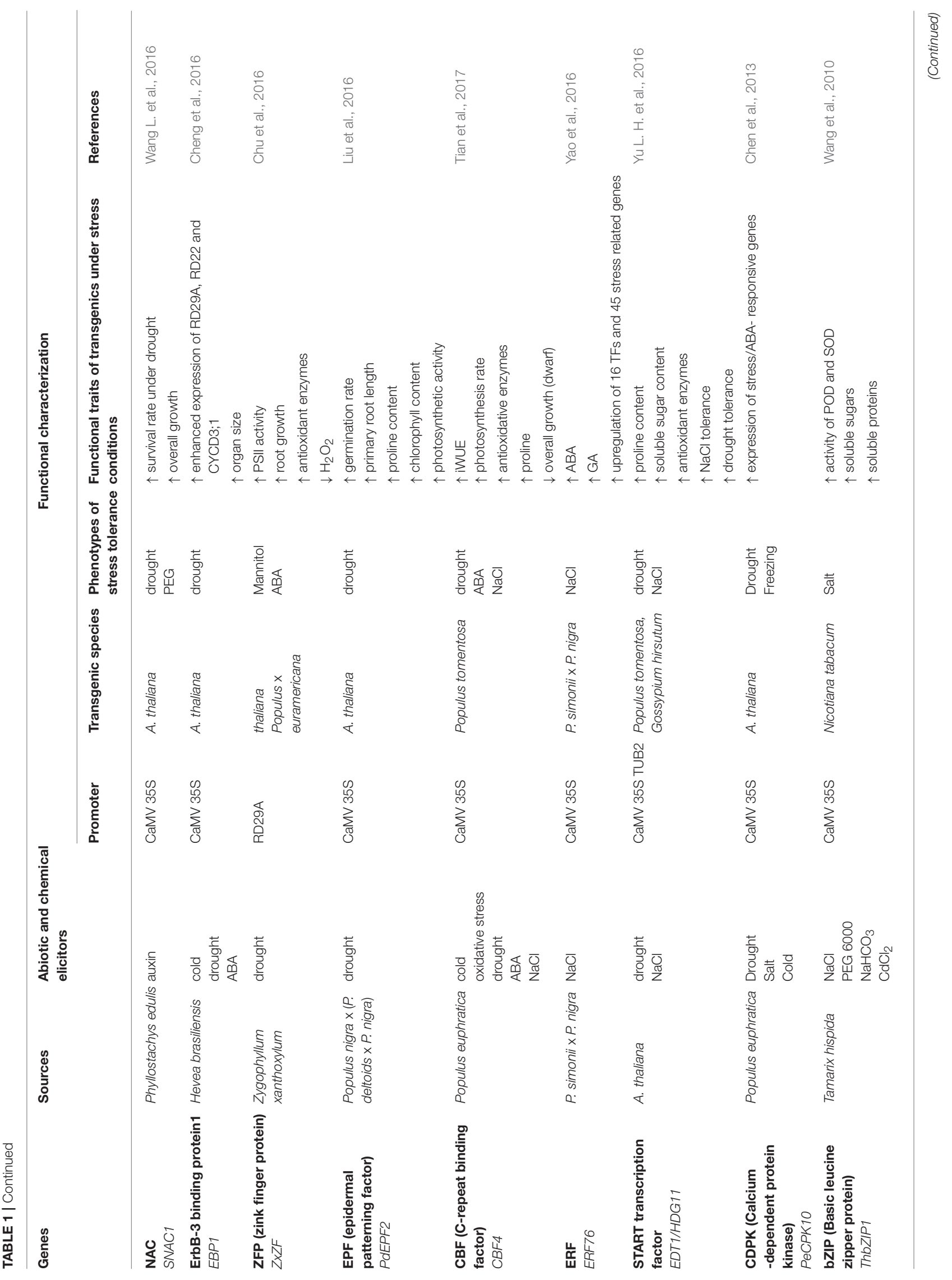




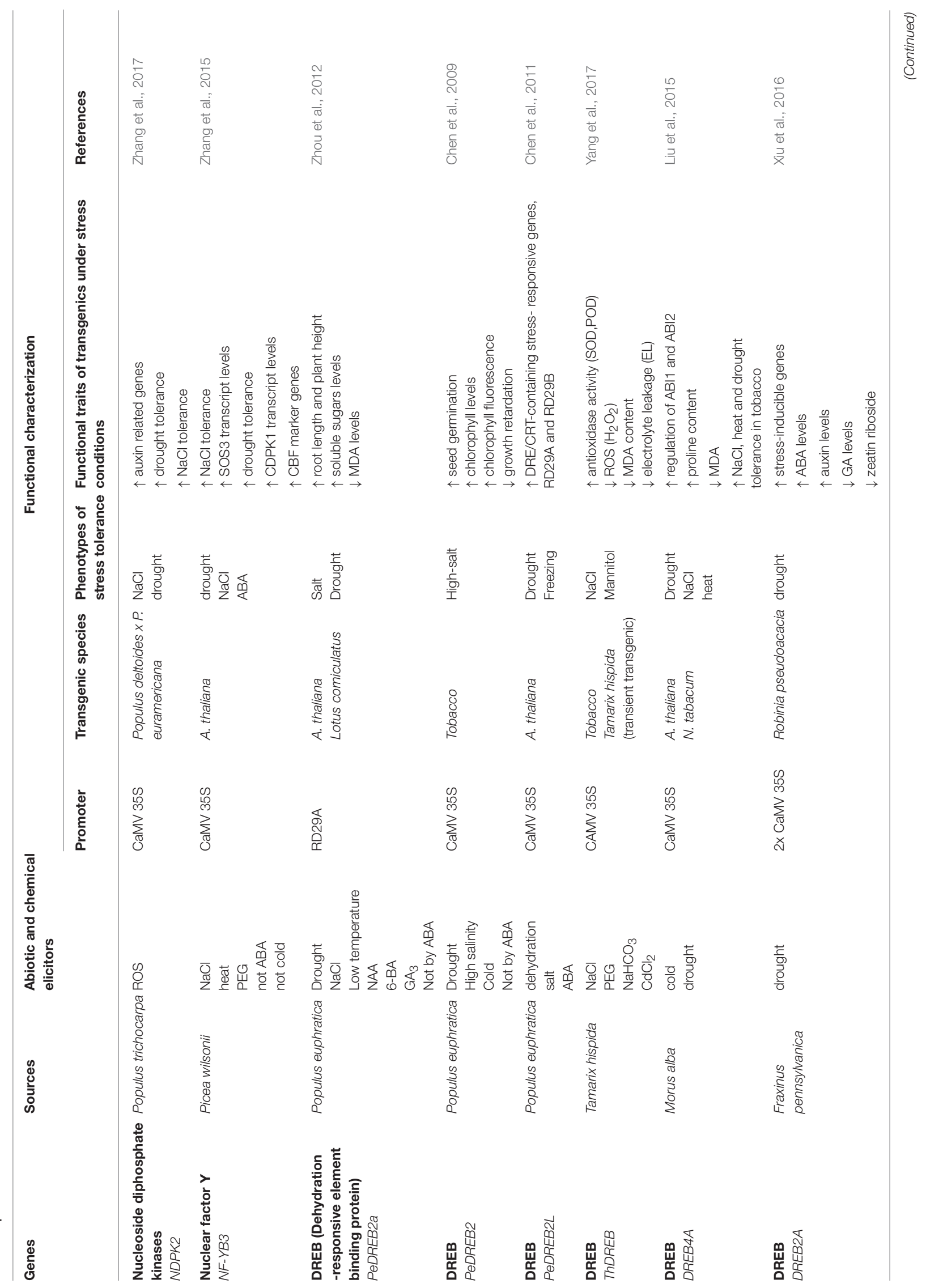




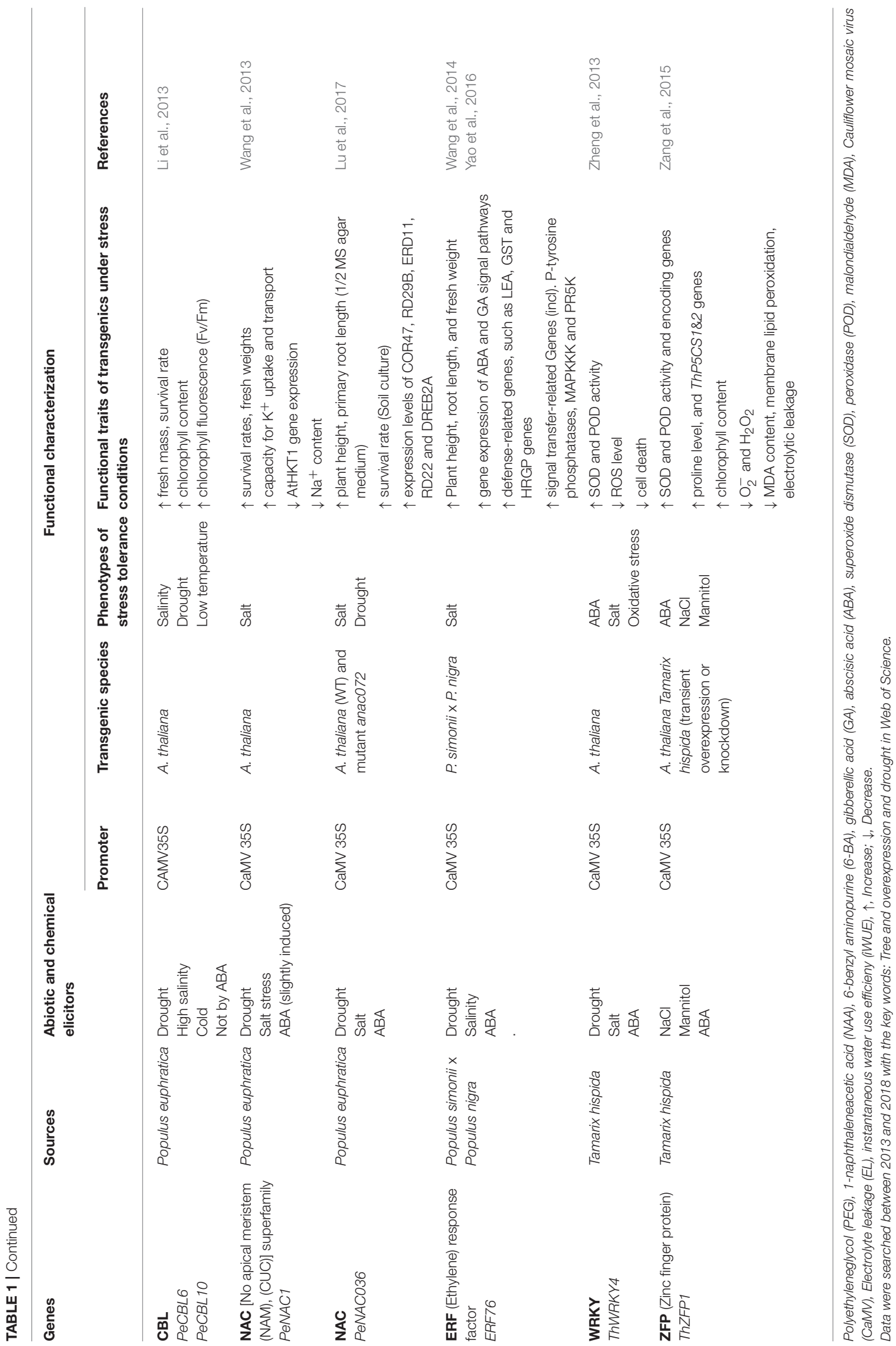




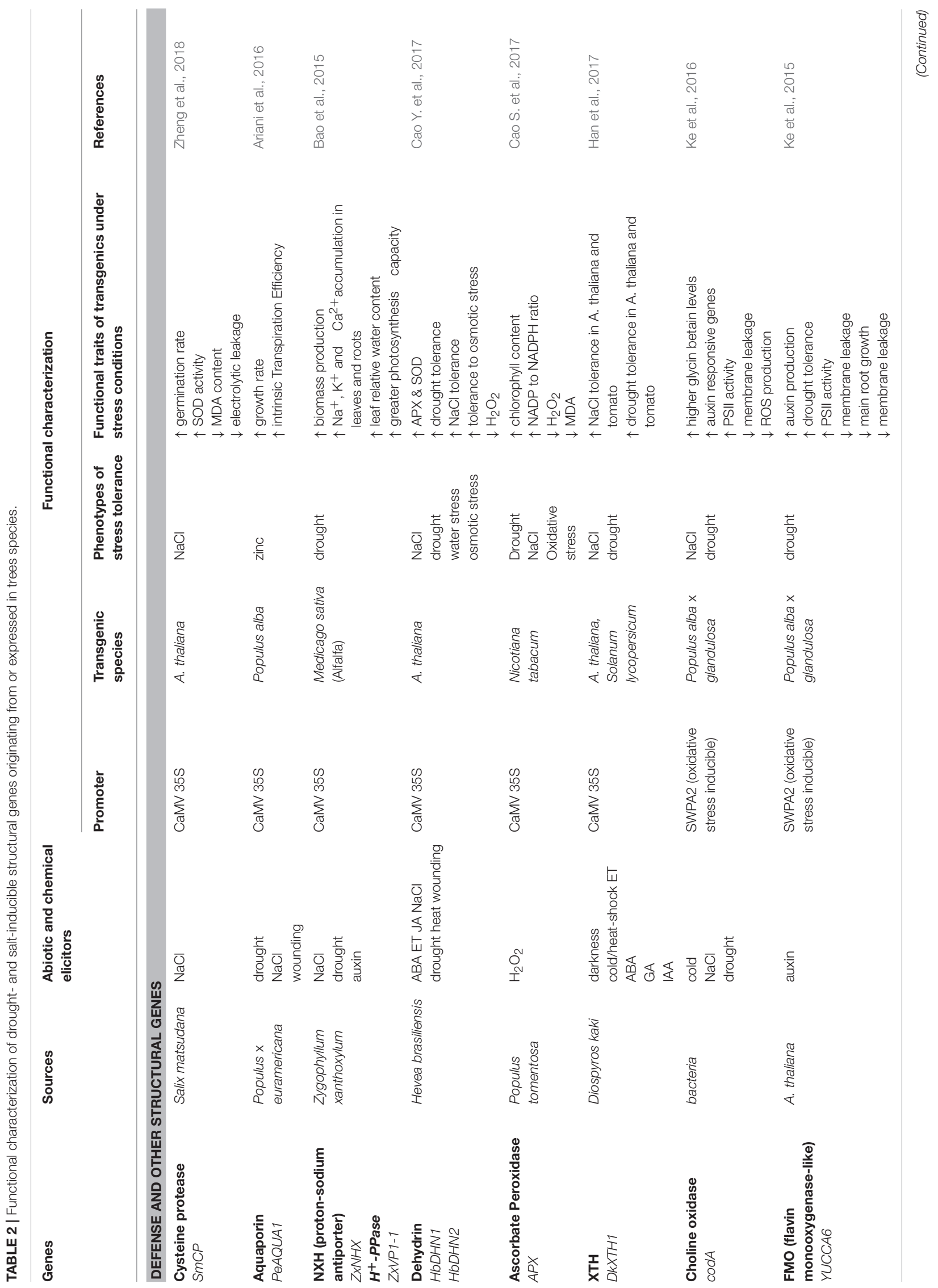




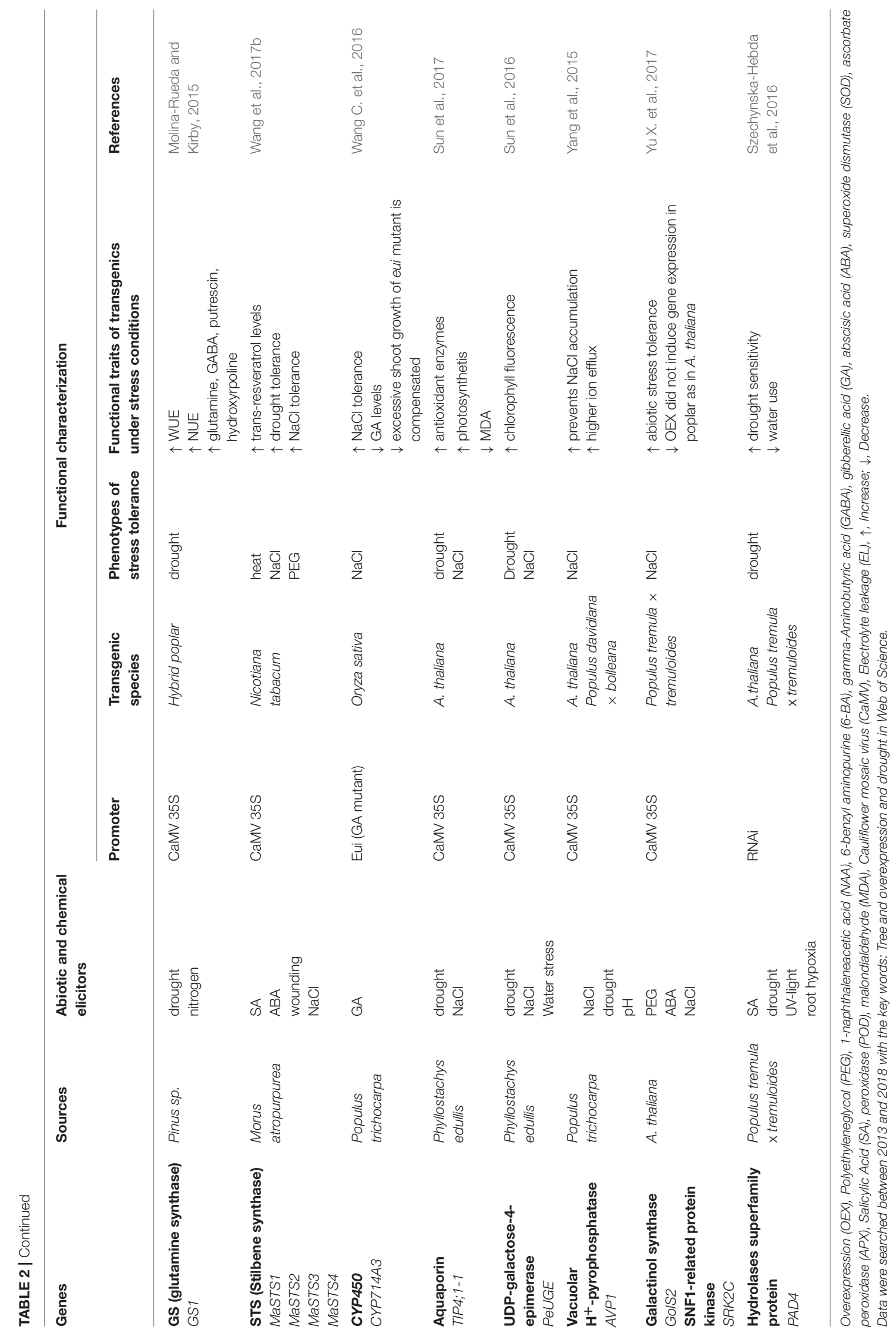


Hevea brasiliensis (rubber), Picea and Pinus (conifers), and Cicer arietium (herbaceous legume crop such chikpea). The target species were model species such as poplars, Arabidopsis and Nicotiana tabacum, but also crops such as alfalfa, cotton, lotus, tomato and rice. Transformation of non-model tree species for enhanced stress tolerance is still rare but recent results showed promise. Overexpression of DREB2A, a gene that forms a hub for drought-stress related gene expression in Robinia pseudoacacia resulted in enhanced drought resistance (Xiu et al., 2016). The drought resistant phenotype was mediated by the formation of deeper roots and decreased oxidative stress, and most likely mediated by effects on the phytohormone balance of the plants (Xiu et al., 2016, Table 1).

Succulence, which occurs in many drought or salt resistant species, is a complex trait that may prove to be useful for drought resistance. Leaf thickness and water content increase with increasing salinity and aridity (Ottow et al., 2005; Nguyen et al., 2017). Succulent leaves exhibit a significant water storage capacity and dilute intrinsic salt concentrations (Ottow et al., 2005; Scholz et al., 2011; Han et al., 2013; Ishii et al., 2014). Overexpression of a putative xyloglucan endotransglucosylase/hydrolase from $P$. euphratica $(P e X T H)$ contributed to salt-induced leaf succulence (Han et al., 2013) by improving cell wall properties to cope with water deficit and high salinity (Cho et al., 2006). Overexpression of a hot pepper (Capsicum annuum) CaXTH3 in guard cells reduced transpiration under dehydration stress, thus, supporting a role of XTHs in drought resistance (Choi et al., 2011).

As highlighted before, the acclimatory responses of trees to drought invoke a multitude of molecular and biochemical changes. Consequently, a focus of many recent genetic approaches was on genes encoding protein kinases and transcription factors to potentially target whole signaling and biochemical pathways instead of single gene products. Overexpression of $C P K$ (calcium-dependent protein kinase, Chen et al., 2013), bZIP (Basic leucine zipper protein, Wang et al., 2010), DREB (dehydration-responsive element-binding protein, Chen et al., 2009, 2011; Zhou et al., 2012; Yang et al., 2017), CBL (calcineurin B-like protein, Li et al., 2013), NAC [no apical meristem (NAM, Wang L. et al., 2016, 2017), ATAF (Arabidopsis transcription activation factor), CUC (cup-shaped cotyledon) superfamily, Wang et al., 2013; Lu et al., 2017], ERF (ethylene response factor, Wang et al., 2014; Yao et al., 2016), WRKY (Zheng et al., 2013), and ZFP (zinc finger proteins, Zang et al., 2015) often resulted in enhanced photosynthesis, higher WUE, higher activity of antioxidative enzymes, lower oxidative damage and improved growth under osmotic stress (Table 1). Examples are still rare where drought and salt responses are not congruent (Table 1). For example, overexpression of a MAPK1 of the MAPK $\mathrm{C}$ family resulted in more salt tolerant but less drought and heat resistant plants but the underlying mechanisms for this difference are speculative (Liu et al., 2017).

ABA is crucial in mediating plant drought responses. Most of the signal transduction and response factors used for stress amelioration are regulated by ABA (Table 1). The receptor RCAR is the first target of ABA and forms a complex with PP2C for stress signaling (Fujita et al., 2011; de Zelicourt et al., 2016). The situation is even more complex because multiple RCARs and PP2Cs exist that are forming combinatorial interaction networks (Tischer et al., 2017). Arabidopsis and hybrid poplar overexpressing RCARs from $P$. trichocarpa were more drought tolerant than the wildtype through decreased water loss and increased osmotic and antioxidative protection ( $\mathrm{Yu} \mathrm{J}$. et al., 2016, 2017). However, there is also fitness trade-off because germination of the overexpressed Arabidopsis seeds is inhibited (Yu J. et al., 2016). The transgenic poplar phenotype was normal and the biomass gain under strong drought stress was higher than that of the controls (Yu J. et al., 2017). HAB1 was suggested to be the ortholog of Arabidopsis PP2C, which is a negative regulator of ABA signaling and acts as co-receptor for RCARs. Arabidopsis overexpressing $H A B 1$ gene from $P$. euphratica lost ABA sensitivity and became more drought sensitive than the wildtype (Chen et al., 2015). Overall, functional characterization of these genes indicated that the core ABA signaling pathway is conserved in poplar and may be a suitable target for genetic engineering.

Studies applying novel gene editing methods (CRISPR/Cas9) to improve drought tolerance are still in their infancy but hold promise for new discoveries. For example, lignin deposition was reduced in poplars in which $M y b 170$ expression was abolished by CRISPR/Cas9 (Xu et al., 2017). Surprisingly, heterologous expression of $M y b 170$ in Arabidopsis uncovered its presence in guard cells, which showed stronger stomatal closure at night and thereby, enhanced drought protection (Xu et al., 2017). This study illustrates that novel functions of genes can be detected by combining CRISPR/Cas9 and overexpression.

\section{CONCLUSIONS AND RESEARCH NEEDS}

Trees are capable of responding to drought stress through a wide variety of cellular and physiological acclimation strategies, which form the basis for genetic improvements of drought tolerance. In particular, overexpression of drought sensing, signal transduction, and drought responsive transcription factors can enhance drought tolerance in a variety of model systems and some economically important woody species. Our overview on transgenic modifications revealed that modifications at the cellular level were the main targets, often using genes from drought or salt tolerant woody species for overexpression. However, systematic studies to clarify if these genes perform better than those from drought sensitive species are lacking. Comparative studies suggest that amplification of distinct gene families such as the SOS pathway in $P$. euphratica, gene duplication, and evolutionary recruitment of distinct metabolites such as ABA for stomatal regulation could also be important avenues for future research. Furthermore, long-term studies under field conditions are still scarce. There is obviously a strong need for testing genetically modified trees in their natural environment because the combination of stress factors such as heat and drought together may overrule the effects of single stressors present under laboratory conditions.

At a wider scale, we have to assert that our mechanistic understanding of the interplay among osmotic regulation, hydraulic adjustment and uptake systems for water and nutrients is still in its infancy. In particular, the root-toshoot communication that sets off a suite of responses leading to morphological changes of the root system is not clear. 
Therefore, an important future task will be to uncover the genetic basis for an optimized resource allocation between biochemical defenses and production of new structures such as deep rooting systems under stressful climatic conditions. Next-generation genomics and phenomics approaches will facilitate a better understanding of phenotype-genotype maps and help to formulate genomic-assisted breeding strategies in forest trees for resistance to drought stress and other osmotic cues.

\section{AUTHOR CONTRIBUTIONS}

AP, SC, CE, and AH drafted and wrote the manuscript together. All authors agreed on the final version of this review.

\section{REFERENCES}

Al Afas, N., Marron, N., and Ceulemans, R. (2006). Clonal variation in stomatal characteristics related to biomass production of 12 poplar (Populus) clones in a short rotation coppice culture. Environ. Exp. Bot. 58, 279-286. doi: 10.1016/j.envexpbot.2005.09.003

Allen, C. D., Breshears, D. D., and McDowell, N. G. (2015). On underestimation of global vulnerability to tree mortality and forest die-off from hotter drought in the Anthropocene. Ecosphere 6:155. doi: 10.1890/ES15-00203.1

Allen, C. D., Macalady, A. K., Chenchouni, H., Bachelet, D., McDowell, N., Vennetier, M., et al. (2010). A global overview of drought and heat-induced tree mortality reveals emerging climate change risks for forests. Forest Ecol. Manag. 259, 660-684. doi: 10.1016/j.foreco.2009.09.001

Almeida-Rodriguez, A. M., Hacke, U. G., and Laur, J. (2011). Influence of evaporative demand on aquaporin expression and root hydraulics of hybrid poplar. Plant Cell Environ. 34, 1318-1331. doi: 10.1111/j.1365-3040.2011.02331.x

Anderegg, W. R. (2015). Spatial and temporal variation in plant hydraulic traits and their relevance for climate change impacts on vegetation. New. Phytol. 205, 1008-1014. doi: 10.1111/nph.12907

Aranda, I., Cano, F. J., Gasc,ó, A., Cochard, H., Nardini, A., Mancha, J. A., et al. (2015). Variation in photosynthetic performance and hydraulic architecture across European beech (Fagus sylvatica L.) populations supports the case for local adaptation to water stress. Tree Physiol. 35, 34-46. doi: 10.1093/treephys/tpu101

Araújo, W. L., Fernie, A. R., and Nunes-Nesi, A. (2011). Control of stomatal aperture: a renaissance of the old guard. Plant Signal. Behav. 6, 1305-1311. doi: $10.4161 / \mathrm{psb} \cdot 6.9 .16425$

Ariani, A., Francini, A., Andreucci, A., and Sebastiani, L. (2016). Over-expression of AQUA1 in Populus alba Villafranca clone increases relative growth rate and water use efficiency, under Zn excess condition. Plant Cell Rep. 35, 289-301. doi: 10.1007/s00299-015-1883-9

Bao, A. K., Du, B. Q., Touil, L, Kang P., Wang, Q. L. and Wang, S. M. (2015). Co-expression of tonoplast Cation/ $\mathrm{H}^{+}$antiporter and $\mathrm{H}^{+}$-pyrophosphatase from xerophyte Zygophyllum xanthoxylum improves alfalfa plant growth under salinity, drought and field conditions. Plant Biotechnol. J. 14, 964-975. doi: $10.1111 /$ pbi.12451

Barberon, M., Vermeer, J. E., De Bellis, D., Wang, P., Naseer, S., Andersen, T. G., et al. (2016). Adaptation of root function by nutrient-induced plasticity of endodermal differentiation. Cell 164, 447-459. doi: 10.1016/j.cell.2015. 12.021

Barchet, G. L., Dauwe, R., Guy, R. D., Schroeder, W. R., Soolanayakanahally, R. Y., Campbell, M. M., et al. (2014). Investigating the drought-stress response of hybrid poplar genotypes by metabolite profiling. Tree Physiol. 34, 1203-1219. doi: 10.1093/treephys/tpt080

Barrs, H. D. (1971). Cyclic variations in stomatal aperture, transpiration, and leaf water potential under constant environmental conditions. Annu. Rev. Plant. Physiol. 22, 223-236. doi: 10.1146/annurev.pp.22.060171.001255

\section{FUNDING}

This work was supported by the European Commission's Seventh Framework Programme (FP7/2012-2017) under the Grant Agreement No. FP7-311929 (WATBIO), the Brain Gain (Rientro dei Cervelli) MIUR professorship (with tenure) for $\mathrm{AH}$, and jointly by the National Natural Science Foundation of China (Grant Nos. 31770643 and 31570587), Beijing Municipal Natural Science Foundation (Grant No. 6182030), the Research Project of the Chinese Ministry of Education (Grant No. 113013A), the Program of Introducing Talents of Discipline to Universities (111 Project, Grant No. B13007) and the Beijing Advanced Innovation Center for Tree Breeding by Molecular Design (Beijing Forestry University).

Berta, M., Giovannelli, A., Sebastiani, F., Camussi, A., and Racchi, M. L. (2010). Transcriptome changes in the cambial region of poplar (Populus alba L.) in response to water deficit. Plant Biology 12, 341-354. doi: 10.1111/j.1438-8677.2009.00320.x

Bogeat-Triboulot, M. B., Brosché, M., Renaut, J., Jouve, L., Thiec, D. L., Fayyaz, P., et al. (2007). Gradual soil water depletion results in reversible changes of gene expression, protein profiles, ecophysiology, and growth performance in Populus euphratica, a poplar growing in arid regions. Plant Physiol. 143, 876-892. doi: 10.1104/pp.106.088708

Bréda, N., Huc, R., Granier, A., and Dreyer, E. (2006). Temperate forest trees and stands under severe drought: a review of ecophysiological responses, adaptation processes and long-term consequences. Ann. For. Sci. 63, 625-644. doi: 10.1051/forest:2006042

Brignolas, F., Thierry, C., Guerrier, G., and Boudouresque, É. (2000). Compared water deficit response of two Populus $\times$ euramericana clones, Luisa Avanzo and Dorskamp. Ann. For. Sci. 57, 261-266. doi: 10.1051/forest:2000117

Brinker, M., Brosché, M., Vinocur, B., Abo-Ogiala, A., Fayyaz, P., Janz, D., et al. (2010). Linking the salt transcriptome with physiological responses of a saltresistant Populus species as a strategy to identify genes important for stress acclimation. Plant Physiol. 154, 1697-1709. doi: 10.1104/pp.110.164152

Brodribb, T. J., Field, T. S., and Sack, L. (2010). Viewing leaf structure and evolution from a hydraulic perspective. Func. Plant Biol. 37, 488-498. doi: 10.1071/FP10010

Brodribb, T. J., and Holbrook, N. M. (2003). Stomatal closure during leaf dehydration, correlation with other leaf physiological traits. Plant Physiol. 132, 2166-2173. doi: 10.1104/pp.103.023879

Brosché, M., Vinocur, B., Alatalo, E. R., Lamminmäki, A., Teichmann, T., Ottow, E. A., et al. (2005). Gene expression and metabolite profiling of Populus euphratica growing in the Negev desert. Genome Biol. 6:R101. doi: 10.1186/gb-2005-6-12-r101

Brunner, I., Herzog, C., Dawes, M. A., Arend, M., and Sperisen, C. (2015). How tree roots respond to drought. Front. Plant Sci. 6:547. doi: 10.3389/fpls.2015.00547

Buckley, T. N. (2005). The control of stomata by water balance. New. Phytol. 168, 275-292. doi: 10.1111/j.1469-8137.2005.01543.x

Cao, S., Du, X.-H., Li, L.-H., Liu, Y.-D., Zhang, L., Pan, X., et al. (2017). Overexpression of Populus tomentosa cytosolic ascorbate peroxidase enhances abiotic stress tolerance in tobacco plants. Russ. J. Plant Physiol. 64, 224-234. doi: 10.1134/S1021443717020029

Cao, Y., Xiang, X., Geng, M., You, Q., and Huang, X. (2017). Effect of HbDHN1 and $\mathrm{HbDHN} 2$ genes on abiotic stress responses in Arabidopsis. Front. Plant Sci. 8:470. doi: 10.3389/fpls.2017.00470

Carsjens, C., Nguyen Ngoc, Q., Guzy, J., Knutzen, F., Meier, I. C., Müller, M., et al. (2014). Intra-specific variations in expression of stress-related genes in beech progenies are stronger than drought-induced responses. Tree Physiol. 34, 1348-1361. doi: 10.1093/treephys/tpu093

Chaves, M. M., Maroco, J. P., and Pereira, J. S. (2003). Understanding plant responses to drought - from genes to the whole plant. Functional Plant Biol. 30, 239-264. doi: 10.1071/fp02076 
Chen, J., Xia, X., and Yin, W. (2009). Expression profiling and functional characterization of a DREB2-type gene from Populus euphratica. Biochem. Biophys. Res. Commun. 378, 483-487. doi: 10.1016/j.bbrc.2008.11.071

Chen, J., Xia, X., and Yin, W. (2011). A poplar DRE-binding protein gene, PeDREB2L, is involved in regulation of defense response against abiotic stress. Gene 483, 36-42. doi: 10.1016/j.gene.2011.05.010

Chen, J., Xue, B., Xia, X., and Yin, W. (2013). A novel calcium-dependent protein kinase gene from Populus euphratica, confers both drought and cold stress tolerance. Biochem. Biophys. Res. Commun. 441, 630-636. doi: 10.1016/j.bbrc.2013.10.103

Chen, J., Zhang, D., Zhang, C., Xia, X., Yin, W., and Tian, Q. (2015). A putative PP2C-encoding gene negatively regulates ABA signaling in Populus euphratica. PLoS ONE 10:e0139466. doi: 10.1371/journal.pone.0139466

Chen, S., Li, J., Fritz, E., Wang, S., and Hüttermann, A. (2002c). Sodium and chloride distribution in roots and transport in three poplar genotypes under increasing $\mathrm{NaCl}$ stress. Forest Ecol. Manag. 168, 217-230. doi: 10.1016/S0378-1127(01)00743-5

Chen, S., Li, J., Wang, S., Fritz, E., Hüttermann, A., and Altman, A. (2003). Effects of $\mathrm{NaCl}$ on shoot growth, transpiration, ion compartmentation, and transport in regenerated plants of Populus euphratica and Populus tomentosa. Can. J. For. Res. 33, 967-975. doi: 10.1139/x03-066

Chen, S., Li, J., Wang, S., Hüttermann, A., and Altman, A. (2001). Salt, nutrient uptake and transport, and $\mathrm{ABA}$ of Populus euphratica; a hybrid in response to increasing soil NaCl. Trees 15, 186-194. doi: 10.1007/s004680100091

Chen, S., Li, J., Wang, T., Wang, S., Polle, A., and Hüttermann, A. (2002b). Osmotic stress and ion-specific effects on xylem abscisic acid and the relevance to salinity tolerance in poplar. J. Plant Growth Regul. 21, 224-233. doi: 10.1007/s00344-002-1001-4

Chen, S., and Polle, A. (2010). Salinity tolerance of Populus. Plant Biol. 12, 317-333. doi: 10.1111/j.1438-8677.2009.00301.x

Chen, S., Wang, S., Aloys Hüttermann Altman, A. (2002a). Xylem abscisic acid accelerates leaf abscission by modulating polyamine and ethylene synthesis in water-stressed intact poplar. Trees, 16, 16-22. doi: 10.1007/s00468-001-0138-2

Chen, S., Wang, S., Altman, A., and Hüttermann, A. (1997). Genotypic variation in drought tolerance of poplar in relation to abscisic acid. Tree Physiol. 17, 797-803.

Cheng, H., Chen, X., Zhu, J., and Huang, H. (2016). Overexpression of a Hevea brasiliensis ErbB-3 Binding protein 1 gene increases drought tolerance and organ size in Arabidopsis. Front. Plant Sci. 7:1703. doi: 10.3389/fpls.2016.01703

Cho, S. K., Kim, J. E., Park, J.-A., Eom, T. J., and Kim, W. T. (2006). Constitutive expression of abiotic stress-inducible hot pepper $\mathrm{CaXTH3}$, which encodes a xyloglucan endotransglucosylase/hydrolase homolog, improves drought and salt tolerance in transgenic Arabidopsis plants. FEBS Lett. 580, 3136-3144. doi: 10.1016/j.febslet.2006.04.062

Choi, J. Y., Seo, Y. S., Kim, S. J., Kim, W. T., and Shin, J. S. (2011). Constitutive expression of CaXTH3, a hot pepper xyloglucan endotransglucosylase/hydrolase, enhanced tolerance to salt and drought stresses without phenotypic defects in tomato plants (Solanum lycopersicum cv. Dotaerang). Plant Cell Rep. 30, 867-877. doi: 10.1007/s00299-010-0989-3

Chu, Y., Zhang, W., Wu, B., Huang, Q., Zhang, B., and Su, X. (2016). Overexpression of the novel Zygophyllum xanthoxylum C2H2-type zinc finger gene ZxZF improves drought tolerance in transgenic Arabidopsis and poplar. Biologia 71, 769-776. doi: 10.1515/biolog-2016-0093

Claeys, H., and Inzé, D. (2013). The agony of choice: how plants balance growth and survival under water-limiting conditions. Plant Physiol. 162, 1768-1779. doi: 10.1104/pp.113.220921

Cocozza, C., Cherubini, P., Regier, N., Saurer, M., Frey, B., and Tognetti, R. (2010). Early effects of water deficit on two parental clones of Populus nigra grown under different environmental conditions. Funct. Plant Biol. 37, 244-254. doi: 10.1071/FP09156

Cohen, D., Bogeat-Triboulot, M. B., Tisserant, E., Balzergue, S., Martin-Magniette, M.-L., Lelandais, G., et al. (2010). Comparative transcriptomics of drought responses in Populus: a meta-analysis of genome-wide expression profiling in mature leaves and root apices across two genotypes. BMC Genomics 11:630. doi: 10.1186/1471-2164-11-630

Couso, L. L., and Fernández, R. J. (2012). Phenotypic plasticity as an index of drought tolerance in three Patagonian steppe grasses. Ann. Bot. 110, 849-857. doi: $10.1093 / \mathrm{aob} / \mathrm{mcs} 147$
Cowan, I. R. (1978). "Stomatal Behaviour and Environment," in Advances in Botanical Research, eds. R. D. Preston and H. W. Woolhouse (London: Academic Press), 117-228.

Daszkowska-Golec, A., and Szarejko, I. (2013). Open or close the gate - stomata action under the control of phytohormones in drought stress conditions. Front. Plant Sci. 4:138. doi: 10.3389/fpls.2013.00138

Davies, W. J., and Bacon, M. A. (2003). "Adaptation of Roots to Drought," in Root Ecology Ecological Studies, eds H. de Kroon and E. T. W. Visser (Berlin, Heidelberg: Springer), 173-192.

de Zelicourt, A., Colcombet, J., and Hirt, H. (2016). The role of MAPK modules and ABA during abiotic stress signaling. Trends Plant Sci. 21, 677-685. doi: 10.1016/j.tplants.2016.04.004

Dietz, S., von Bülow, J., Beitz, E., and Nehls, U. (2011). The aquaporin gene family of the ectomycorrhizal fungus Laccaria bicolor: lessons for symbiotic functions. New. Phytol. 190, 927-940. doi: 10.1111/j.1469-8137.2011.03651.x

Dluzniewska, P., Gessler, A., Dietrich, H., Schnitzler, J.-P., Teuber, M., and Rennenberg, H. (2007). Nitrogen uptake and metabolism in Populus $\times$ canescens as affected by salinity. New. Phytol. 173, 279-293. doi: 10.1111/j.1469-8137.2006.01908.x

Ehlting, B., Dluzniewska, P., Dietrich, H., Selle, A., Teuber, M., Hänsch, R., et al. (2007). Interaction of nitrogen nutrition and salinity in Grey poplar (Populus tremula $\times$ alba). Plant Cell Environ. 30, 796-811. doi: $10.1111 / j .1365-3040.2007 .01668 . x$

Ellison, D., Morris, C. E., Locatelli, B., Sheil, D., Cohen, J., Murdiyarso, D., et al. (2017). Trees, forests and water: Cool insights for a hot world. Glob. Environ. Change 43, 51-61. doi: 10.1016/j.gloenvcha.2017.01.002

FAO (2016). Global Forest Resources Assessment 2015: How Are the World's Forests Changing? Avaialable online at: http://www.fao.org/resources/infographics/ infographics-details/en/c/325836/

Fischer, U., and Polle, A. (2010). "Populus Responses to Abiotic Stress," in Genetics and Genomics of Populus Plant Genetics and Genomics: Crops and Models, eds S. Jansson, R. P. Bhalerao, and A. T. Groover (New York, NY: Springer), 225-246. doi: 10.1007/978-1-4419-1541-2_11

Fox, A. R., Maistriaux, L. C., and Chaumont, F. (2017). Toward understanding of the high number of plant aquaporin isoforms and multiple regulation mechanisms. Plant Sci. 264, 179-187. doi: 10.1016/j.plantsci.2017.07.021

Fujii, H., Chinnusamy, V., Rodrigues, A., Rubio, S., Antoni, R., Park, S. Y., et al. (2009). In vitro reconstitution of an abscisic acid signalling pathway. Nature 462, 660-664. doi: 10.1038/nature08599

Fujita, Y., Fujita, M., Shinozaki, K., and Yamaguchi-Shinozaki, K. (2011). ABA-mediated transcriptional regulation in response to osmotic stress in plants. J. Plant Res. 124, 509-525. doi: 10.1007/s10265-0110412-3

Gebre, G. M., Kuhns, M. R., and Brandle, J. R. (1994). Organic solute accumulation and dehydration tolerance in three water-stressed Populus deltoides clones. Tree Physiol. 14, 575-587.

Geiger, D., Maierhofer, T., Al-Rasheid, K. A., Scherzer, S., and Mumm, P., Liese, A., et al. (2011). Stomatal closure by fast abscisic acid signaling is mediated by the guard cell anion channel SLAH3 and the Receptor RCAR1. Sci. Signal. 4:ra32. doi: 10.1126/scisignal.2001346

Giovannelli, A., Deslauriers, A., Fragnelli, G., Scaletti, L., Castro, G., Rossi, S., et al. (2007). Evaluation of drought response of two poplar clones (Populus $\times$ canadensis Mönch 'I-214' and P. deltoides Marsh. 'Dvina') through high resolution analysis of stem growth. J. Exp. Bot. 58, 2673-2683. doi: $10.1093 / \mathrm{jxb} / \mathrm{erm} 117$

González-Carranza, Z. H., Lozoya-Gloria, E., and Roberts, J. A. (1998). Recent developments in abscission: shedding light on the shedding process. Trends Plant Sci. 3, 10-14.

Hacke, U. G., Sperry, J. S., Pockman, W. T., Davis, S. D., and McCulloh, K. A. (2001). Trends in wood density and structure are linked to prevention of xylem implosion by negative pressure. Oecologia 126, 457-461. doi: $10.1007 / \mathrm{s} 004420100628$

Hacke, U. G., Sperry, J. S., Wheeler, J. K., and Castro, L. (2006). Scaling of angiosperm xylem structure with safety and efficiency. Tree Physiol. 26, 689-701. doi: 10.1093/treephys/26.6.689

Hadley, J. L., and Smith, W. K. (1990). Influence of leaf surface wax and leaf area to water content ratio on cuticular transpiration in western conifers, U.S.A. Can. J. For. Res. 20, 1306-1311. doi: 10.1139/x90-173 
Hamanishi, E. T., and Campbell, M. M. (2011). Genome-wide responses to drought in forest trees. Forestry 84, 273-283. doi: 10.1093/forestry/cpr012

Hamanishi, E. T., Thomas, B. R., and Campbell, M. M. (2012). Drought induces alterations in the stomatal development program in Populus. J. Exp. Bot. 63, 4959-4971. doi: 10.1093/jxb/ers177

Han, Y., Han, S., Ban, Q., He, Y., Jin, M., and Rao, J. (2017). Overexpression of persimmon DkXTH1 enhanced tolerance to abiotic stress and delayed fruit softening in transgenic plants. Plant Cell. Rep. 36, 583-596. doi: 10.1007/s00299-017-2105-4

Han, Y., Wang, W., Sun, J., Ding, M., Zhao, R., Deng, S., et al. (2013). Populus euphratica XTH overexpression enhances salinity tolerance by the development of leaf succulence in transgenic tobacco plants. J. Exp. Bot. 64:4225. doi: 10.1093/jxb/ert229

Hanin, M., Brini, F., Ebel, C., Toda, Y., Takeda, S., and Masmoudi, K. (2011). Plant dehydrins and stress tolerance. Plant Signal. Behav. 6, 1503-1509. doi: $10.4161 / \mathrm{psb} .6 .10 .17088$

Harfouche, A., Meilan, R., and Altman, A. (2014). Molecular and physiological responses to abiotic stress in forest trees and their relevance to tree improvement. Tree Physiol. 34, 1181-1198. doi: 10.1093/treephys/tpu012

Hasanuzzaman, M., Nahar, K., Gill, S. S., and Fujita, M. (2013). "Drought stress responses in plants, oxidative stress, and antioxidant defense," in Climate Change and Plant Abiotic Stress Tolerance, eds N. Tuteja and S. S. Gill (Weinheim: Wiley-VCH Verlag GmbH \& Co), 209-250.

Hennig, A. (2016). Drought Stress Response Of Tetraploid Hybrid Aspen (Populus tremula L. x P. tremuloides Michx.) of Protoplast Fusion Experiments. Available online at: https://ediss.uni-goettingen.de/handle/11858/00-1735-0000-00288754-5

Hennig, A., Kleinschmit, J. R., Schoneberg, S., Löffler, S., Janßen, A., and Polle, A. (2015). Water consumption and biomass production of protoplast fusion lines of poplar hybrids under drought stress. Front. Plant Sci. 6:330. doi: 10.3389/fpls.2015.00330

Ishii, H. R., Azuma, W., Kuroda, K., and Sillett, S. C. (2014). Pushing the limits to tree height: could foliar water storage compensate for hydraulic constraints in Sequoia sempervirens? Funct. Ecol. 28, 1087-1093. doi: $10.1111 / 1365-2435.12284$

Iuchi, S., Kobayashi, M., Taji, T., Naramoto, M., Seki, M., Kato, T., et al. (2001). Regulation of drought tolerance by gene manipulation of 9-cisepoxycarotenoid dioxygenase, a key enzyme in abscisic acid biosynthesis in Arabidopsis. Plant J. 27, 325-333. doi: 10.1046/j.1365-313x.2001.01096.x

Janz, D., Behnke, K., Schnitzler, J. P., Kanawati, B., Schmitt-Kopplin, P., and Polle, A. (2010). Pathway analysis of the transcriptome and metabolome of salt sensitive and tolerant poplar species reveals evolutionary adaption of stress tolerance mechanisms. BMC Plant Biol. 10:150. doi: 10.1186/1471-2229-10-150

Janz, D., Lautner, S., Wildhagen, H., Behnke, K., Schnitzler, J. P., Rennenberg, H., et al. (2012). Salt stress induces the formation of a novel type of "pressure wood" in two Populus species. New. Phytol. 194, 129-141. doi: 10.1111/j.1469-8137.2011.03975.x

Janz, D., and Polle, A. (2012). Harnessing salt for woody biomass production. Tree Physiol. 32, 1-3. doi: 10.1093/treephys/tpr127

Jarvis, P. G., and Jarvis, M. S. (1963). The water relations of tree seedlings.: IV. some aspects of the tissue water relations and drought resistance. Physiol. Plant. 16, 501-516. doi: 10.1111/j.1399-3054.1963.tb08327.x

Jin, X., Zimmermann, J., Polle, A., and Fischer, U. (2015). Auxin is a longrange signal that acts independently of ethylene signaling on leaf abscission in Populus. Front. Plant. Sci. 6:634. doi: 10.3389/fpls.2015.00634

Jones, H. G. (1993). "Drought tolerance and water-use efficiency", in Water deficits: Plant responses from cell to community, eds J. A. C. Smith and H. Griffiths (Oxford: BIOS Scientific Publishers), 193-203.

Junghans, U., Polle, A., Düchting, P., Weiler, E., Kuhlman, B., Gruber, F., et al. (2006). Adaptation to high salinity in poplar involves changes in xylem anatomy and auxin physiology. Plant Cell Environ. 29, 1519-1531

Kanno, Y., Hanada, A., Chiba, Y., Ichikawa, T., Nakazawa, M., Matsui, M., et al. (2012). Identification of an abscisic acid transporter by functional screening using the receptor complex as a sensor. Proc. Natl. Acad. Sci. U. S. A. 109, 9653-9658. doi: 10.1073/pnas.1203567109

Ke, Q., Wang, Z., Ji, C. Y., Jeong, J. C., Lee, H.-S., Li, H., et al. (2015). Transgenic poplar expressing Arabidopsis YUCCA6 exhibits auxin-overproduction phenotypes and increased tolerance to abiotic stress. Plant Physiol. Biochem. 94, 19-27. doi: 10.1016/j.plaphy.2015.05.003

Ke, Q., Wang, Z., Ji, C. Y., Jeong, J. C., Lee, H.-S., Li, H., et al. (2016). Transgenic poplar expressing $\operatorname{cod} A$ exhibits enhanced growth and abiotic stress tolerance. Plant Physiol. Biochem. 100, 75-84. doi: 10.1016/j.plaphy.2016. 01.004

Klein, T. (2014). The variability of stomatal sensitivity to leaf water potential across tree species indicates a continuum between isohydric and anisohydric behaviours. Funct. Ecol. 28, 1313-1320. doi: 10.1111/1365-2435.12289

Koiwai, H., Nakaminami, K., Seo, M., Mitsuhashi, W., Toyomasu, T., and Koshiba, T. (2004). Tissue-specific localization of an abscisic acid biosynthetic enzyme, AAO3, in Arabidopsis. Plant Physiol. 134, 1697-1707. doi: $10.1104 /$ pp.103.036970

Kuromori, T., Miyaji, T., Yabuuchi, H., Shimizu, H., Sugimoto, E., Kamiya, A., et al. (2010). ABC transporter AtABCG25 is involved in abscisic acid transport and responses. Proc. Natl. Acad. Sci. U. S. A. 107, 2361-2366. doi: 10.1073/pnas.0912516107

Kuromori, T., Seo, M., and Shinozaki, K. (2018). ABA transport and plant water stress responses. Trends Plant Sci. 23, 513-522. doi: 10.1016/j.tplants.2018.04.001

Laur, J., and Hacke, U. G. (2014). The role of water channel proteins in facilitating recovery of leaf hydraulic conductance from water stress in Populus trichocarpa. PLoS ONE 9:e111751. doi: 10.1371/journal.pone.0111751

Laurance, W. F. (1998). A crisis in the making: responses of Amazonian forests to land use and climate change. Trends Ecol. Evol. 13, 411-415. doi: 10.1016/S0169-5347(98)01433-5

Laurance, W. F. (2004). Forest-climate interactions in fragmented tropical landscapes. Philos. Trans. R. Soc. Lond. B. Biol. Sci. 359, 345-352. doi: 10.1098/rstb.2003.1430

Leuschner, C., and Meier, I. C. (2018). The ecology of Central European tree species: Trait spectra, functional trade-offs, and ecological classification of adult trees. Perspect. Plant Ecol. Syst. 33, 89-103. doi: 10.1016/j.ppees.2018.05.003

Levitt, J. (1980). Responses of Plants to Environmental Stress: Chilling, Freezing, and High Temperature Stresses. Responses of Plants to Environmental Stress, 2nd $E d n$, Vol. 1 Available online at: https://www.cabdirect.org/cabdirect/abstract/ 19802605739

Li, D.-D., Xia, X.-L., Yin, W.-L., and Zhang, H.-C. (2013). Two poplar calcineurin B-like proteins confer enhanced tolerance to abiotic stresses in transgenic Arabidopsis thaliana. Biol. Plant. 57, 70-78. doi: 10.1007/s10535-012-0251-7

Li, T., Sun, J., Bi, Y., and Peng, Z. (2016). Overexpression of an MYB-Related gene FvMYB1 from Fraxinus velutina increases tolerance to salt stress in transgenic tobacco. J. Plant Growth Regul. 35, 632-645. doi: 10.1007/s00344-015-9565-y

Li, Y., Zhao, M., Motesharrei, S., Mu, Q., Kalnay, E., and Li, S. (2015). Local cooling and warming effects of forests based on satellite observations. Nat. Commun. 6:6603. doi: $10.1038 /$ ncomms7603

Liu, C., Wei, C., Zhang, M., Xu, Y., Xiang, Z., and Zhao, A. (2017). Mulberry $M n M A P K 1$, a group C mitogen-activated protein kinase gene, endowed transgenic Arabidopsis with novel responses to various abiotic stresses. Plant Cell Tiss. Organ Cult. 131, 151-162. doi: 10.1007/s11240-017-1272-x

Liu, S., Wang, C., Jia, F., An, Y., Liu, C., Xia, X., et al. (2016). Secretory peptide PdEPF2 enhances drought tolerance by modulating stomatal density and regulates ABA response in transgenic Arabidopsis thaliana. Plant Cell Tiss. Organ Cult. 125, 419-431. doi: 10.1007/s11240-016-0957-X

Liu, X.-Q., Liu, C.-Y., Guo, Q., Zhang, M., Cao, B.-N., Xiang, Z.-H., et al. (2015). Mulberry transcription factor MnDREB4A confers tolerance to multiple abiotic stresses in transgenic tobacco. PLoS ONE 10:e0145619. doi: 10.1371/journal.pone.0145619

Lorenz, W. W., Alba, R., Yu, Y.-S., Bordeaux, J. M., Simões, M., and Dean, J. F. (2011). Microarray analysis and scale-free gene networks identify candidate regulators in drought-stressed roots of loblolly pine ( $P$. taeda $L$.). BMC Genomics 12:264. doi: 10.1186/1471-2164-12-264

Lu, X., Zhang, X., Duan, H., Lian, C., Liu, C., Yin, W., et al. (2017). Three stressresponsive NAC transcription factors from Populus euphratica differentially regulate salt and drought tolerance in transgenic plants. Physiol. Plant. 162, 73-97. doi: 10.1111/ppl.12613

Luo, Z. B., Janz, D., Jiang, X., Göbel, C., Wildhagen, H., Tan, Y., et al. (2009). Upgrading root physiology for stress tolerance by ectomycorrhizas: insights 
from metabolite and transcriptional profiling into reprogramming for stress anticipation. Plant Physiol. 151, 1902-1917. doi: 10.1104/pp.109.143735

Ma, Q., Yue, L.-J., Zhang, J.-L., Wu, G.-Q., Bao, A.-K., and Wang, S.M. (2012). Sodium chloride improves photosynthesis and water status in the succulent xerophyte Zygophyllum xanthoxylum. Tree Physiol. 32, 4-13. doi: 10.1093/treephys/tpr098

Ma, T., Wang, J., Zhou, G., Yue, Z., Hu, Q., Chen, Y., et al. (2013). Genomic insights into salt adaptation in a desert poplar. Nat. Commun. 4:2797. doi: $10.1038 /$ ncomms 3797

Malone, S. L. (2017). Monitoring changes in water use efficiency to understand drought induced tree mortality. Forests 8:365. doi: 10.3390/f8100365

Marron, N., Delay, D., Petit, J.-M., Dreyer, E., Kahlem, G., Delmotte, F. M., et al. (2002). Physiological traits of two Populus $\times$ euramericana clones, Luisa Avanzo and Dorskamp, during a water stress and re-watering cycle. Tree Physiol. 22, 849-858. doi: 10.1093/treephys/22.12.849

Marron, N., Dreyer, E., Boudouresque, E., Delay, D., Petit, J.-M., Delmotte, F. M., et al. (2003). Impact of successive drought and re-watering cycles on growth and specific leaf area of two Populus $\mathrm{x}$ canadensis (Moench) clones, "Dorskamp" and "Luisa_Avanzo." Tree Physiol. 23, 1225-1235. doi: 10.1093/treephys/23.18.1225

Martorell, S., Medrano, H., Tomàs, M., Escalona, J. M., Flexas, J., and DiazEspejo, A. (2015). Plasticity of vulnerability to leaf hydraulic dysfunction during acclimation to drought in grapevines: an osmotic-mediated process. Physiol. Plant. 153, 381-391. doi: 10.1111/ppl.12253

McDowell, N., Pockman William, T., Allen Craig, D., Breshears David, D., Cobb, N., Kolb, T., et al. (2008). Mechanisms of plant survival and mortality during drought: why do some plants survive while others succumb to drought? New. Phytol. 178, 719-739. doi: 10.1111/j.1469-8137.2008.02436.x

Mishra, B., Gupta, D. K., Pfenninger, M., Hickler, T., Langer, E., Nam, B., et al. (2018). A reference genome of the European beech (Fagus sylvatica L.). Gigascience 7:giy063. doi: 10.1093/gigascience/giy063

Molina-Rueda, J. J., and Kirby, E. G. (2015). Transgenic poplar expressing the pine GS1a show alterations in nitrogen homeostasis during drought. Plant Physiol. Biochem. 94, 181-190. doi: 10.1016/j.plaphy.2015.06.009

Monclus, R., Dreyer, E., Villar, M., Delmotte, F. M., Delay, D., Petit, J.-M., et al. (2006). Impact of drought on productivity and water use efficiency in 29 genotypes of Populus deltoides $\times$ Populus nigra. New. Phytol. 169, 765-777. doi: 10.1111/j.1469-8137.2005.01630.x

Movahedi, A., Zhang, J. X., Gao, P. H., Yang, Y., Wang, L. K., Yin, T .M., et al. (2015). Expression of the chickpea CarNAC3 gene enhances salinity and drought tolerance in transgenic poplars. Plant Cell Tissue Organ Cult. 120, 141-154. doi: 10.1007/s11240-014-0588-z

Munné-Bosch, S., and Alegre, L. (2004). Die and let live: leaf senescence contributes to plant survival under drought stress. Funct. Plant Biol. 31, 203-216. doi: $10.1071 /$ fp03236

Naser, L., Kourosh, V., Bahman, K., and Reza, A. (2010). Soluble sugars and proline accumulation play a role as effective indices for drought tolerance screening in Persian walnut (Juglans regia L.) during germination. Fruits 65, 97-112. doi: 10.1051 /fruits/20010005

Nguyen, A., and Lamant, A. (1989). Variation in growth and osmotic regulation of roots of water-stressed maritime pine (Pinus pinaster Ait.) provenances. Tree Physiol. 5, 123-133.

Nguyen, H. T., Meir, P., Sack, L., Evans, J. R., Oliveira, R. S., and Ball, M. C. (2017). Leaf water storage increases with salinity and aridity in the mangrove Avicennia marina: integration of leaf structure, osmotic adjustment and access to multiple water sources. Plant Cell Environ. 40, 1576-1591. doi: 10.1111/pce.12962

NSIDC (2018). National Snow Ice and Data Center. Available online at: https:// nsidc.org/arcticseaicenews/

Orlovic, S., Guzina, V., Krstic, B., and Merkulov, L. (1998). Genetic variability in anatomical, physiological and growth characteristics of hybrid poplar (Populus $\times$ euramericana Dode (Guinier)) and eastern cottonwood (Populus deltoides Bartr.) clones. Silvae Genet. 47, 183-190.

Ottow, E. A., Brinker, M., Teichmann, T., Fritz, E., Kaiser, W., Brosch,é, M., et al. (2005). Populus euphratica displays apoplastic sodium accumulation, osmotic adjustment by decreases in calcium and soluble carbohydrates, and develops leaf succulence under salt stress. Plant Physiol. 139:1762. doi: 10.1104/pp.105.069971
Pallara, G., Giovannelli, A., Traversi, M. L., Camussi, A., and Racchi, M. L. (2012). Effect of water deficit on expression of stress-related genes in the cambial region of two contrasting poplar clones. J. Plant Growth Regul. 31, 102-112. doi: 10.1007/s00344-011-9223-y

Parent, B., Hachez, C., Redondo, E., Simonneau, T., Chaumont, F., and Tardieu, F. (2009). Drought and abscisic acid effects on aquaporin content translate into changes in hydraulic conductivity and leaf growth rate: a trans-scale approach. Plant Physiol. 149, 2000-2012. doi: 10.1104/pp.108.130682

Parker, J. (1956). Drought resistance in woody plants. Bot. Rev. 22, 241-289.

Passioura, J. B. (2002). Soil conditions and plant growth. Plant Cell Environ. 25, 311-318. doi: 10.1046/j.0016-8025.2001.00802.x

Paul, S., Wildhagen, H., Janz, D., and Polle, A. (2018). Drought effects on the tissue- and cell-specific cytokinin activity in poplar. AoB PLANTS 10:plx067. doi: 10.1093/aobpla/plx067.

Perdiguero, P., Collada, C., Barbero, M., del, C., García Casado, G., Cervera, M. T., et al. (2012). Identification of water stress genes in Pinus pinaster Ait. by controlled progressive stress and suppression-subtractive hybridization. Plant Physiol. Biochem. 50, 44-53. doi: 10.1016/j.plaphy.2011.09.022

Peter, M., Kohler, A., Ohm, R. A., Kuo, A., Krützmann, J., Morin, E., et al. (2016). Ectomycorrhizal ecology is imprinted in the genome of the dominant symbiotic fungus Cenococcum geophilum. Nat. Commun. 7:12662. doi: $10.1038 /$ ncomms 12662

Plomion, C., Aury, J.-M., Amselem, J., Leroy, T., Murat, F., Duplessis, S., et al. (2018). Oak genome reveals facets of long lifespan. Nat. Plants 4, 440-452. doi: 10.1038/s41477-018-0172-3

Polle, A., Altman, A., and Jiang, X. (2006). "Towards genetic engineering for drought tolerance in trees," in Tree Transgenesis, eds M. Fladung and D. Ewald (Berlin, Heidelberg: Springer), 275-297.

Polle, A., and Chen, S. (2015). On the salty side of life: molecular, physiological and anatomical adaptation and acclimation of trees to extreme habitats. Plant Cell Environ. 38, 1794-1816. doi: 10.1111/pce.12440

Rennenberg, H., Loreto, F., Polle, A., Brilli, F., Fares, S., Beniwal, R. S., et al. (2006). Physiological responses of forest trees to heat and drought. Plant Biol. 8, 556-571. doi: 10.1055/s-2006-924084

Reyer, C. P. O., Brouwers, N., Rammig, A., Brook, B. W., Epila, J., Grant, R. F., et al. (2015). Forest resilience and tipping points at different spatio-temporal scales: approaches and challenges. J. Ecol. 103, 5-15. doi: 10.1111/1365-2745.12337

Roman, D. T., Novick, K. A., Brzostek, E. R., Dragoni, D., Rahman, F., and Phillips, R. P. (2015). The role of isohydric and anisohydric species in determining ecosystem-scale response to severe drought. Oecologia 179, 641-654. doi: 10.1007/s00442-015-3380-9

Schaller, N., Sparrow, S. N., Massey, N. R., Bowery, A., Miller, J., Wilson, S., et al. (2018). Ensemble of European regional climate simulations for the winter of 2013 and 2014 from HadAM3P-RM3P. Sci. Data 5:180057. doi: $10.1038 /$ sdata.2018.57

Scholz, F. G., Phillips, N. G., Bucci, S. J., Meinzer, F. C., and Goldstein, G. (2011). "Hydraulic capacitance: biophysics and functional significance of internal water sources in relation to tree size," in Size- and Age-Related Changes in Tree Structure and Function Tree Physiology, eds F. C. Meinzer, B. Lachenbruch, and T. E. Dawson (Dordrecht: Springer), 341-361

Secchi, F., and Zwieniecki, M. A. (2011). Sensing embolism in xylem vessels: the role of sucrose as a trigger for refilling. Plant Cell Environ. 34, 514-524. doi: 10.1111/j.1365-3040.2010.02259.x

Shi, Y., Li, J., Shao, J., Deng, S., Wang, R., Li, N., et al. (2010). Effects of Stockosorb and Luquasorb polymers on salt and drought tolerance of Populus popularis. Sci. Horticulturae 124, 268-273. doi: 10.1016/j.scienta.2009.12.031

Skelton, R. P., West, A. G., and Dawson, T. E. (2015). Predicting plant vulnerability to drought in biodiverse regions using functional traits. Proc. Natl. Acad. Sci. U. S. A. $112,5744-5749$. doi: $10.1073 /$ pnas. 1503376112

Smart, L. B., Moskal, W. A., Cameron, K. D., and Bennett, A. B. (2001). MIP genes are down-regulated under drought stress in Nicotiana glauca. Plant Cell Physiol. 42, 686-693. doi: 10.1093/pcp/pce085

Sperry, J. S., and Love, D. M. (2015). What plant hydraulics can tell us about responses to climate-change droughts. New. Phytol. 207, 14-27. doi: $10.1111 / \mathrm{nph} .13354$

Stålfelt, M. G. (1955). The stomata as a hydrophotic regulator of the water deficit of the plant. Physiol. Plant. 8, 572-593. doi: 10.1111/j.1399-3054.1955.tb07753.x 
Sun, H., Li, L., Lou, Y., Zhao, H., Yang, Y., and Gao, Z. (2016). Cloning and preliminary functional analysis of PeUGE gene from moso bamboo (Phyllostachys edulis). DNA Cell Biol. 35, 706-714. doi: 10.1089/dna.2016.3389

Sun, H., Li, L., Lou, Y., Zhao, H., Yang, Y., Wang, S., et al. (2017). The bamboo aquaporin gene PeTIP4;1-1confers drought and salinity tolerance in transgenic Arabidopsis. Plant Cell Rep. 36, 597-609. doi: 10.1007/s00299-017-2106-3

Sussmilch, F. C., Brodribb, T. J., and McAdam, S. A. M. (2017). What are the evolutionary origins of stomatal responses to abscisic acid (ABA) in land plants? J. Integr. Plant Biol. 59, 240-260. doi: 10.1111/jipb.12523

Szechynska-Hebda, M., Czarnocka, W., Hebda, M., and Karpinski, S. (2016). PAD4, LSD1 and EDS1 regulate drought tolerance, plant biomass production, and cell wall properties. Plant Cell Rep. 35, 527-539. doi: 10.1007/s00299-015-1901-y

Tan, B.-C., Joseph, L. M., Deng, W.-T., Liu, L., Li, Q.-B., Cline, K., et al. (2003). Molecular characterization of the Arabidopsis 9cis epoxycarotenoid dioxygenase gene family. Plant J. 35, 44-56. doi: 10.1046/j.1365-313X.2003.01786.x

Tardieu, F., and Simonneau, T. (1998). Variability among species of stomatal control under fluctuating soil water status and evaporative demand: modelling isohydric and anisohydric behaviours. J. Exp. Bot. 49, 419-432. doi: 10.1093/jxb/49.Special_Issue.419

Tian, Q., Chen, J., Wang, D., Wang, H.-L., Liu, C., Wang, S., et al. (2017). Overexpression of a Populus euphratica CBF4 gene in poplar confers tolerance to multiple stresses. Plant Cell Tiss. Organ Cult. 128, 391-407. doi: 10.1007/s11240-016-1118-y

Tischer, S. V., Wunschel, C., Papacek, M., Kleigrewe, K., Hofmann, T., Christmann, A., et al. (2017). Combinatorial interaction network of abscisic acid receptors and coreceptors from Arabidopsis thaliana. Proc. Natl. Acad. Sci. U. S. A. 114, 10280-10285. doi: 10.1073/pnas.1706593114

Tung, S. A., Smeeton, R., White, C. A., Black, C. R., Taylor, I. B., Hilton, H. W., et al, (2008). Over-expression of LeNCED1 in tomato (Solanum lycopersicum L.) with the rbcS3C promoter allows recovery of lines that accumulate very high levels of abscisic acid and exhibit severe phenotypes. Plant Cell Environ. 31, 968-981. doi: 10.1111/j.1365-3040.2008.01812.x

Tyree, M. T., and Ewers, F. W. (1991). The hydraulic architecture of trees and other woody plants. New. Phytologist 119, 345-360. doi: 10.1111/j.1469-8137.1991.tb00035.x

van der Werf, G. R., Dempewolf, J., Trigg, S. N., Randerson, J. T., Kasibhatla, P. S., Giglio, L., et al. (2008). Climate regulation of fire emissions and deforestation in equatorial Asia. Proc. Natl. Acad. Sci. U. S. A. 105, 20350-20355. doi: 10.1073/pnas.0803375105

Wang, C., Wang, L., Yang, C., and Wang, Y. (2017a). Identification, phylogeny, and transcript profiling of aquaporin genes in response to abiotic stress in Tamarix hispida. Tree Genet. Genomes 13:81. doi: 10.1007/s11295-017-1163-7

Wang, C., Yang, Y., Wang, H., Ran, X., Li, B., Zhang, J., et al. (2016). Ectopic expression of a cytochrome P450 monooxygenase gene PtCYP714A3 from Populus trichocarpa reduces shoot growth and improves tolerance to salt stress in transgenic rice. Plant Biotechnol. J. 14, 1838-1851. doi: 10.1111/pbi.12544

Wang, C., Zhi, S., Liu, C., Xu, F., Zhao, A., Wang, X., et al. (2017b). Characterization of stilbene synthase genes in mulberry (Morus atropurpurea) and metabolic engineering for the production of resveratrol in Escherichia coli. J. Agric. Food Chem. 65, 1659-1668. doi: 10.1021/acs.jafc.6b05212

Wang, J. Y., Wang, J. P., and He-Yuan (2013). A Populus euphratica NAC protein regulating $\mathrm{Na}^{+} / \mathrm{K}^{+}$homeostasis improves salt tolerance in Arabidopsis thaliana. Gene 521, 265-273. doi: 10.1016/j.gene.2013.03.068

Wang, L., Li, Z., Lu, M., and Wang, Y. (2017). ThNAC13, a NAC transcription factor from Tamarix hispida, confers salt and osmotic stress tolerance to transgenic Tamarix and Arabidopsis. Front. Plant Sci. 8:635. doi: $10.3389 /$ fpls.2017.00635

Wang, L., Zhao, H., Chen, D., Li, L., Sun, H., Lou, Y., et al. (2016). Characterization and primary functional analysis of a bamboo NAC gene targeted by miR164b. Plant Cell Rep. 35, 1371-1383. doi: 10.1007/s00299-016-1970-6

Wang, S., Yao, W., Wei, H., Jiang, T., and Zhou, B. (2014). Expression patterns of ERF genes underlying abiotic stresses in di-haploid Populus simonii $\times$ P. nigra. Sci. World J. 2014:745091. doi: 10.1155/2014/745091

Wang, W., Vinocur, B., and Altman, A. (2003). Plant responses to drought, salinity and extreme temperatures: towards genetic engineering for stress tolerance. Planta 218, 1-14. doi: 10.1007/s00425-003-1105-5
Wang, Y., Gao, C., Liang, Y., Wang, C., Yang, C., and Liu, G. (2010). A novel bZIP gene from Tamarix hispida mediates physiological responses to salt stress in tobacco plants. J. Plant Physiol. 167, 222-230. doi: 10.1016/j.jplph.2009.09.008

Wasilewska, A., Vlad, F., Sirichandra, C., Redko, Y., Jammes, F., Valon, C., et al. (2008). An update on abscisic acid signaling in plants and more. Mol. Plant 1 , 198-217. doi: $10.1093 / \mathrm{mp} / \mathrm{ssm} 022$

Wildhagen, H., Paul, S., Allwright, M., Smith, H. K., Malinowska, M., Schnabel, S. K., et al. (2018). Genes and gene clusters related to genotype and drought-induced variation in saccharification potential, lignin content and wood anatomical traits in Populus nigra. Tree Physiol. 38, 320-339. doi: 10.1093/treephys/tpx054

Wilkins, O., Waldron, L., Nahal, H., Provart, N. J., and Campbell, M. M. (2009). Genotype and time of day shape the Populus drought response. Plant J. 60, 703-715. doi: 10.1111/j.1365-313X.2009.03993.x

Wolfe, B. T., Sperry, J. S., and Kursar, T. A. (2016). Does leaf shedding protect stems from cavitation during seasonal droughts? A test of the hydraulic fuse hypothesis. New. Phytol. 212, 1007-1018. doi: 10.1111/nph. 14087

Xing, H. T., Guo, P., Xia, X. L., and Yin, W. L. (2011). PdERECTA, a leucine-rich repeat receptor-like kinase of poplar, confers enhanced water use efficiency in Arabidopsis. Planta 234, 229-241. doi: 10.1007/s00425-011-1389-9

Xiu, Y., Iqbal, A., Zhu, C., Wu, G., Chang, Y., Li, N., et al. (2016). Improvement and transcriptome analysis of root architecture by overexpression of Fraxinus pennsylvanica DREB2A transcription factor in Robinia pseudoacacia L. 'Idaho.' Plant Biotechnol. J. 14, 1456-1469. doi: 10.1111/pbi.12509

Xu, C., Fu, X., Liu, R., Guo, L., Ran, L., Li, C., et al. (2017). PtoMYB170 positively regulates lignin deposition during wood formation in poplar and confers drought tolerance in transgenic Arabidopsis. Tree Physiol. 37, 1713-1726. doi: 10.1093/treephys/tpx093

Xu, H., Kemppainen, M., El Kayal, W., Lee, S. H., Pardo, A. G., Cooke, J. E. K., et al. (2015). Overexpression of Laccaria bicolor aquaporin JQ585595 alters root water transport properties in ectomycorrhizal white spruce (Picea glauca) seedlings. New. Phytol. 205, 757-770. doi: 10.1111/nph.13098

Yang, G., Yu, L., Zhang, K., Zhao, Y., Guo, Y., and Gao, C. (2017). A ThDREB gene from Tamarix hispida improved the salt and drought tolerance of transgenic tobacco and T. hispida. Plant Physiol. Biochem. 113, 187-197. doi: 10.1016/j.plaphy.2017.02.007

Yang, Y., Tang, R. J., Li, B., Wang, H. H., Jin, Y. L., Jiang, C. M., et al. (2015). Overexpression of a Populus trichocarpa $\mathrm{H}^{+}$-pyrophosphatase gene PtVP1.1 confers salt tolerance on transgenic poplar. Tree Physiol. 35, 663-677. doi: 10.1093/treephys/tpv027

Yao, W., Wang, S., Zhou, B., and Jiang, T. (2016). Transgenic poplar overexpressing the endogenous transcription factor $E R F 76$ gene improves salinity tolerance. Tree Physiol. 36, 896-908. doi: 10.1093/treephys/tpw004

Yu, J., Ge, H., Wang, X., Tang, R., Wang, Y., Zhao, F., et al. (2017). Overexpression of pyrabactin resistance-like abscisic acid receptors enhances drought, osmotic, and cold tolerance in transgenic poplars. Front. Plant Sci. 8:1752. doi: $10.3389 /$ fpls.2017.01752

Yu, J., Yang, L., Liu, X., Tang, R., Wang, Y., Ge, H., et al. (2016). Overexpression of poplar pyrabactin resistance-like abscisic acid receptors promotes abscisic acid sensitivity and drought resistance in transgenic Arabidopsis. PLoS ONE 11:e0168040. doi: 10.1371/journal.pone.0168040

Yu, L. H., Wu, S. J., Peng, Y. S., Liu, R. N., Chen, X., Zhao, P., et al. (2016). Arabidopsis EDT1/HDG11 improves drought and salt tolerance in cotton and poplar and increases cotton yield in the field. Plant Biotechnol. J 14, 72-84. doi: $10.1111 /$ pbi. 12358

Yu, X., Ohtani, M., Kusano, M., Nishikubo, N., Uenoyama, M., Umezawa, T., et al. (2017). Enhancement of abiotic stress tolerance in poplar by overexpression of key Arabidopsis stress response genes, AtSRK2C and AtGols2. Mol. Breeding 37:57. doi: 10.1007/s11032-016-0618-0

Zang, D., Wang, C., Ji, X., and Wang, Y. (2015). Tamarix hispida zinc finger protein ThZFP1 participates in salt and osmotic stress tolerance by increasing proline content and SOD and POD activities. Plant Sci. 235, 111-121. doi: 10.1016/j.plantsci.2015.02.016

Zhang, H., Zhu, H., Pan, Y., Yu, Y., Luan, S., and Li, L. (2014). A DTX/MATE-type transporter facilitates abscisic acid efflux and modulates ABA sensitivity and drought tolerance in Arabidopsis. Mol. Plant 7, 1522-1532. doi: $10.1093 / \mathrm{mp} / \mathrm{ssu} 063$ 
Zhang, J., Movahedi, A., Sang, M., Wei, Z., Xu, J., Wang, X., et al. (2017). Functional analyses of NDPK2 in Populus trichocarpa and overexpression of PtNDPK2 enhances growth and tolerance to abiotic stresses in transgenic poplar. Plant Physiol. Biochem. 117, 61-74. doi: 10.1016/j.plaphy.2017.05.019

Zhang, T., Zhang, D., Liu, Y., Luo, C., Zhou, Y., and Zhang, L. (2015). Overexpression of a NF-YB3 transcription factor from Picea wilsonii confers tolerance to salinity and drought stress in transformed Arabidopsis thaliana. Plant Physiol. Biochem. 94, 153-164. doi: 10.1016/j.plaphy.2015.05.001

Zheng, L., Chen, S., Xie, L., Lu, Z., Liu, M., Han, X., et al. (2018). Overexpression of cysteine protease gene from Salix matsudana enhances salt tolerance in transgenic Arabidopsis. Environ. Exp. Bot. 147, 53-62. doi: 10.1016/j.envexpbot.2017.11.008

Zheng, L., Liu, G., Meng, X., Liu, Y., Ji, X., Li, Y., et al. (2013). A WRKY gene from Tamarix hispida, ThWRKY4, mediates abiotic stress responses by modulating reactive oxygen species and expression of stress-responsive genes. Plant Mol. Biol. 82, 303-320. doi: 10.1007/s11103-013-0063-y
Zhou, M. L., Ma, J. T., Zhao, Y. M., Wei, Y. H., Tang, Y. X., and Wu, Y. M. (2012). Improvement of drought and salt tolerance in Arabidopsis and Lotus corniculatus by overexpression of a novel DREB transcription factor from Populus euphratica. Gene 506, 10-17. doi: 10.1016/j.gene.2012.06.089

Conflict of Interest Statement: The authors declare that the research was conducted in the absence of any commercial or financial relationships that could be construed as a potential conflict of interest.

Copyright $\odot 2019$ Polle, Chen, Eckert and Harfouche. This is an open-access article distributed under the terms of the Creative Commons Attribution License (CC BY). The use, distribution or reproduction in other forums is permitted, provided the original author(s) and the copyright owner(s) are credited and that the original publication in this journal is cited, in accordance with accepted academic practice. No use, distribution or reproduction is permitted which does not comply with these terms. 